\title{
Nicotinic receptors on rat alveolar macrophages dampen ATP-induced increase in cytosolic calcium concentration
}

\author{
Zbigniew Mikulski ${ }^{1 *}$, Petra Hartmann ${ }^{1 \dagger}$, Gitte Jositsch ${ }^{1,2}$, Zbigniew Zasłona $^{3}$, Katrin S Lips ${ }^{1,4}$, Uwe Pfeil ${ }^{1}$, \\ Hjalmar Kurzen ${ }^{5}$, Jürgen Lohmeyer ${ }^{3}$, Wolfgang G Clauss' ${ }^{2}$, Veronika Grau', Martin Fronius ${ }^{2}$, Wolfgang Kummer ${ }^{1}$
}

\begin{abstract}
Background: Nicotinic acetylcholine receptors (nAChR) have been identified on a variety of cells of the immune system and are generally considered to trigger anti-inflammatory events. In the present study, we determine the nAChR inventory of rat alveolar macrophages (AM), and investigate the cellular events evoked by stimulation with nicotine.

Methods: Rat AM were isolated freshly by bronchoalveolar lavage. The expression of nAChR subunits was analyzed by RT-PCR, immunohistochemistry, and Western blotting. To evaluate function of nAChR subunits, electrophysiological recordings and measurements of intracellular calcium concentration $\left(\left[\mathrm{Ca}^{2+}\right]_{\mathrm{i}}\right)$ were conducted.

Results: Positive RT-PCR results were obtained for nAChR subunits $\alpha 3, \alpha 5, \alpha 9, \alpha 10, \beta 1$, and $\beta 2$, with most stable expression being noted for subunits $\alpha 9, \alpha 10, \beta 1$, and $\beta 2$. Notably, mRNA coding for subunit $\alpha 7$ which is proposed to convey the nicotinic anti-inflammatory response of macrophages from other sources than the lung was not detected. RT-PCR data were supported by immunohistochemistry on AM isolated by lavage, as well as in lung tissue sections and by Western blotting. Neither whole-cell patch clamp recordings nor measurements of $\left[\mathrm{Ca}^{2+}\right]_{\mathrm{i}}$ revealed changes in membrane current in response to $\mathrm{ACh}$ and in $\left[\mathrm{Ca}^{2+}\right]_{\mathrm{i}}$ in response to nicotine, respectively. However, nicotine $(100 \mu \mathrm{M})$, given 2 min prior to ATP, significantly reduced the ATP-induced rise in $\left[\mathrm{Ca}^{2+}\right]_{i}$ by $30 \%$. This effect was blocked by $\alpha$-bungarotoxin and did not depend on the presence of extracellular calcium.

Conclusions: Rat AM are equipped with modulatory nAChR with properties distinct from ionotropic nAChR mediating synaptic transmission in the nervous system. Their stimulation with nicotine dampens ATP-induced $\mathrm{Ca}^{2+}{ }_{-}$ release from intracellular stores. Thus, the present study identifies the first acute receptor-mediated nicotinic effect on AM with anti-inflammatory potential.
\end{abstract}

\section{Background}

Alveolar macrophages (AM) hold a key position in initiating pulmonary inflammatory responses by secreting tumor necrosis factor $\alpha$ (TNF $\alpha$ ) and several additional cytokines and chemokines. It has been demonstrated that TNF $\alpha$ production and release from peritoneal macrophages can be largely inhibited by neurally released ACh thereby attenuating systemic inflammatory responses. This physiological mechanism has been

\footnotetext{
*Correspondence: zmikulski@gmail.com

† Contributed equally

'Institute for Anatomy and Cell Biology, University of Giessen Lung Center, Justus-Liebig-University Giessen, Aulweg 123, D-35385 Giessen, Germany Full list of author information is available at the end of the article
}

termed "cholinergic anti-inflammatory pathway" [1]. Studies on monocyte-derived human macrophages and on nicotinic acetylcholine receptor (nAChR) deficient mouse strains revealed that the $\mathrm{nAChR} \alpha 7$ subunit is essential for this anti-inflammatory pathway [2]. It has been demonstrated that stimulation of mouse peritoneal macrophages with nicotine is associated with activation of the Jak2-STAT3 signaling pathway and with inhibition of the release of pro-inflammatory cytokines and chemokines [3]. Several lines of evidence show that stimulation of the cholinergic anti-inflammatory pathway and application of nicotinic agonists can be beneficial in experimental endotoxemia and sepsis [1-3]. The $\alpha 7$ 
subunit is one of 9 different known ligand-binding $\alpha$ subunits ( $\alpha 1-\alpha 7$ and $\alpha 9-\alpha 10)$ that assemble to homoor heteropentamers, partially with additional participation of $\beta$ subunits, to form a functional nAChR. All these receptors are ligand-gated cation channels, and they are distinct from each other with respect to ligand affinity and to preference for mono- or divalent cations [4]. There is growing evidence that neuronal-type ion channels are not formed by nAChR subunits in cells of the immune system [5-7].

In view of the natural occurrence of nAChR ligands in the alveolar compartment (e.g. choline) and of the clinical relevance of nicotine contained within cigarette smoke, the potential presence of a cholinergic anti-inflammatory pathway in the lung deserves high attention. Indeed, $\mathrm{nAChR}$ agonists reduce acid- and gram-negative sepsis-induced acute lung injury in mice and rats $[8,9]$ and tumour necrosis factor- $\alpha$ (TNF- $\alpha$ ) release into the lung compartment after intrapulmonary delivery of LPS in mice [10]. Here, we hypothesized that cholinergic anti-inflammation is operative through modulation of AM function. We established an inventory of nAChR subunit expression in rat AM by RT-PCR and immunohistochemistry. Whole-cell patch-clamp measurements were conducted to investigate whether classical, ion-conducting $\mathrm{nAChR}$ are operative in AM. The effect of nicotine upon macrophage stimulation with ATP, a "host tissue damage" or "danger signal" [11], was investigated by the method of real-time imaging for cytosolic $\mathrm{Ca}^{2+}$ responses. We demonstrate that there is a nicotinic anti-inflammatory pathway operative in rat AM. The receptor subtypes involved and intracellular signaling pathways, as identified so far, differ from that known from the nervous system. Potentially, this allows for selective pharmacological intervention and therapeutic use.

\section{Methods}

\section{Alveolar macrophage isolation}

Female Wistar rats (8-10 weeks old) were obtained from the local animal breeding facility (Institute of Physiology, Justus-Liebig-University, Giessen, Germany) and kept under conventional conditions. Wild type C57BL6N specific-pathogen free (SPF) mice were purchased from Charles River (Sulzfeld, Germany). Mice deficient for the $\alpha 7 \mathrm{nAChR}$ subunit were obtained from Jackson Laboratory (Bar Harbor, USA) and bred in SPF conditions by the local animal breeding facility using heterozygotes as breeders. Male and female mice were used throughout the study between 8 and 12 weeks of age. All animals were kept with free access to food and water. Animal care and animal experiments were performed following the current version of the German
Law on the Protection of Animals as well as the NIH "principles of laboratory animal care".

Animals were killed by inhalation of an overdose of isoflurane (Abbott, Wiesbaden, Germany). For isolation of rat AM, the lung was carefully removed, cannulated via the trachea, and bronchoalveolar lavage (BAL) was performed using $10 \times 5 \mathrm{ml}$ ice-cold PBS containing (in $\mathrm{mM}): \mathrm{KCl} 2.68, \mathrm{KH}_{2} \mathrm{PO}_{4} 1.47, \mathrm{NaCl} 136.89, \mathrm{Na}_{2} \mathrm{HPO}_{4}$ 8.10 (pH 7.3) (PAA, Pasching, Austria). Mouse AM were isolated according to previously described protocols [12]. The lavage fluid was centrifuged at $400 \times \mathrm{g}$ for $5 \mathrm{~min}$ at $4^{\circ} \mathrm{C}$, and the pellet was resuspended in PBS or DMEM/F12 GlutaMax-I medium (Invitrogen, Karlsruhe, Germany). BAL cells were monitored by microscopy, and preparations containing erythrocytes were discarded. Isolated macrophages were used for subsequent analysis by RT-PCR, immunocytochemistry, Western blotting, electrophysiological recordings and measurements of intracellular calcium concentration $\left(\left[\mathrm{Ca}^{2+}\right]_{\mathrm{i}}\right)$.

\section{RT-PCR}

Total RNA was isolated from BAL cells $(\mathrm{n}=7$ rats and $\mathrm{n}=5$ C57BL6N mice) using RNeasy Mini Kit (Qiagen, Hilden, Germany). Genomic DNA contaminations were removed by DNase I digestion for $15 \mathrm{~min}$ at $37^{\circ} \mathrm{C}, 1 \mathrm{U} /$ reaction (Invitrogen). cDNA synthesis was performed with iScript (Bio-Rad, Munich, Germany) or SuperScript II (Invitrogen) kits using $1 \mu \mathrm{g}$ total RNA. The cDNAs were amplified with the subunit specific primer pairs spanning at least one intron (Table. 1 and 2). Hypoxanthine guanine phosphoribosyl transferase 1 (HPRT1) and $\beta$-microglobulin primers were used to monitor cDNA integrity for rat and mouse samples, respectively. For amplification, $2.5 \mu \mathrm{l}$ buffer II $(100 \mathrm{mM}$ Tris- $\mathrm{HCl}$, $500 \mathrm{mM} \mathrm{KCl}, \mathrm{pH} 8.3), 2 \mu \mathrm{l} 15 \mathrm{mM} \mathrm{MgCl} 2,0.6 \mu \mathrm{ldNTP}$ (10 mM each), $0.6 \mu \mathrm{l}$ of each primer $(10 \mu \mathrm{M})$, and 0.125 $\mu \mathrm{l}$ AmpliTaq Gold polymerase (5 U/ $\mu \mathrm{l}$, Applied Biosystems, Foster City, USA) were added to $1 \mu \mathrm{l}$ of cDNA, and made up to a final volume of $25 \mu$ with $\mathrm{H}_{2} \mathrm{O}$. Cycling conditions were $10 \mathrm{~min}$ at $95^{\circ} \mathrm{C}, 40$ cycles with $20 \mathrm{~s}$ at $94^{\circ} \mathrm{C}, 20 \mathrm{~s}$ at $60^{\circ} \mathrm{C}, 20 \mathrm{~s}$ at $72^{\circ} \mathrm{C}$, and a final extension at $72^{\circ} \mathrm{C}$ for $7 \mathrm{~min}$. PCR products were separated by electrophoresis on a $1.5 \%$ agarose gel in Trisacetate-EDTA buffer. Sequencing of PCR products was done by MWG Biotech (Ebersbach, Germany). Positive controls for primers detecting rat subunits $\alpha 1$ and $\beta 1$ were done using reversely transcribed total RNA from rat muscle tissue. Rat lung was used as a positive control for subunits $\beta 2-\beta 4$. For other rat primer pairs, rat DRG were used as a positive control. Mouse lung was used as a positive control for all primers detecting mouse nAChR subunits. Negative controls were 
Table 1 Rat primer sequences used in the study

\begin{tabular}{|c|c|c|c|c|}
\hline \multirow{2}{*}{$\begin{array}{l}\text { Target } \\
\mathrm{nAChR} \\
\alpha 1\end{array}$} & \multicolumn{2}{|c|}{ Sequence } & \multirow{2}{*}{$\begin{array}{l}\text { Length } \\
171 \mathrm{bp}\end{array}$} & \multirow{2}{*}{$\begin{array}{l}\text { Accession No. } \\
\text { [GenBank: } \\
\text { NM_024485] }\end{array}$} \\
\hline & for. & AGCTCACCGCTGTCCTCCT & & \\
\hline & rev. & GGATCAGTTGCAGTCCCACA & & \\
\hline \multirow[t]{2}{*}{$\begin{array}{l}\mathrm{nAChR} \\
\alpha 2\end{array}$} & for. & CGCGTCCCTTCAGAGATGAT & $114 \mathrm{bp}$ & $\begin{array}{l}\text { [GenBank: } \\
\text { L31622] }\end{array}$ \\
\hline & rev. & CACAGTGCCCGTGAAGAA & & \\
\hline \multirow[t]{2}{*}{$\begin{array}{l}n A C h R \\
\alpha 3\end{array}$} & for. & СCTCCCTGTCTATCGGGTCT & $161 \mathrm{bp}$ & $\begin{array}{l}\text { [GenBank: } \\
\text { X03440] }\end{array}$ \\
\hline & rev. & GCCGGATGATCTCGTTGTAA & & \\
\hline \multirow[t]{2}{*}{$\begin{array}{l}\text { nAChR } \\
\alpha 4\end{array}$} & for. & GGACCCTGGTGACTACGAGA & $137 \mathrm{bp}$ & $\begin{array}{l}\text { [GenBank: } \\
\text { NM_024354] }\end{array}$ \\
\hline & rev. & CATAGAACAGGTGGGCCTTG & & \\
\hline \multirow[t]{2}{*}{$\begin{array}{l}\mathrm{nAChR} \\
\alpha 5\end{array}$} & for. & TGGAACACCTGAGCGACAAG & $284 \mathrm{bp}$ & $\begin{array}{l}\text { [GenBank: } \\
\text { NM_017078] }\end{array}$ \\
\hline & rev. & CGTGACAGTGCCGTTGTACC & & \\
\hline \multirow[t]{2}{*}{$\begin{array}{l}\mathrm{nAChR} \\
\alpha 6\end{array}$} & for. & TGGTGTTAAGGACCCCAAAA & $142 \mathrm{bp}$ & $\begin{array}{l}\text { [GenBank: } \\
\text { NM_057184] }\end{array}$ \\
\hline & rev. & GCTGCTGGCTTAACCTCTTG & & \\
\hline \multirow[t]{2}{*}{$\begin{array}{l}\text { nAChR } \\
\alpha 7\end{array}$} & for. & ACATTGACGTTCGCTGGTTC & $235 \mathrm{bp}$ & $\begin{array}{l}\text { [GenBank: } \\
\text { L31619] }\end{array}$ \\
\hline & rev. & CTACGGCGCATGGTTACTGT & & \\
\hline \multirow[t]{2}{*}{$\begin{array}{l}\text { nAChR } \\
\alpha 9\end{array}$} & for. & CGTGGGATCGAGACCAGTAT & $142 \mathrm{bp}$ & $\begin{array}{l}\text { [GenBank: } \\
\text { AY574257] }\end{array}$ \\
\hline & rev. & TCATATCGCAGCACCACATT & & \\
\hline \multirow[t]{2}{*}{$\begin{array}{l}\text { nAChR } \\
\alpha 10\end{array}$} & for. & GTGCCACTCATCGGAAAGTA & $107 \mathrm{bp}$ & $\begin{array}{l}\text { [GenBank: } \\
\text { NM_022639] }\end{array}$ \\
\hline & rev. & TGTGCATTAGGGCCACAGTA & & \\
\hline \multirow[t]{2}{*}{$\begin{array}{l}\mathrm{nAChR} \\
\beta 1\end{array}$} & for. & TCCTAAGCGTGGTGGTCCTC & $151 \mathrm{bp}$ & $\begin{array}{l}\text { [GenBank: } \\
\text { NM_01258] }\end{array}$ \\
\hline & rev. & TGTGGTTCGGGTAGTTGGTC & & \\
\hline \multirow[t]{2}{*}{$\begin{array}{l}\mathrm{nAChR} \\
\beta 2\end{array}$} & for. & AGCCTTCTTTGGCTGTGCTC & $116 \mathrm{bp}$ & $\begin{array}{l}\text { [GenBank: } \\
\text { NM_019297] }\end{array}$ \\
\hline & rev. & GAGCCGTTAGTAGCTGGACGA & & \\
\hline \multirow[t]{2}{*}{$\begin{array}{l}\mathrm{nAChR} \\
\beta 3\end{array}$} & for. & CACTCTGCGCTTGAAAGGAA & $196 \mathrm{bp}$ & $\begin{array}{l}\text { [GenBank: } \\
\text { NM_133597] }\end{array}$ \\
\hline & rev. & GCGGACCCATTTCTGGTAAC & & \\
\hline \multirow[t]{2}{*}{$\begin{array}{l}\mathrm{nAChR} \\
\beta 4\end{array}$} & for. & CACTCGCGGTTCCATTGTAG & $159 \mathrm{bp}$ & $\begin{array}{l}\text { [GenBank: } \\
\text { NM_052806] }\end{array}$ \\
\hline & rev. & CGGGTITTGTTCAGGAGGTC & & \\
\hline \multirow[t]{2}{*}{$\mathrm{P} 2 \mathrm{Y} 1$} & for. & AGGAAAGCTTCCAGGAGGAG & $203 \mathrm{bp}$ & $\begin{array}{l}\text { [GenBank: } \\
\text { NM_012800] }\end{array}$ \\
\hline & rev. & GGCCAATAGAATGTTGCTTCTT & & \\
\hline \multirow[t]{2}{*}{$\mathrm{P} 2 \mathrm{Y} 2$} & for. & CATGCGAGTGAAGAACTGGA & $209 \mathrm{bp}$ & $\begin{array}{l}\text { [GenBank: } \\
\text { NM_017255] }\end{array}$ \\
\hline & rev. & GGCAGCAGCACATACTTGAA & & \\
\hline \multirow[t]{2}{*}{$\mathrm{P} 2 \mathrm{Y}_{4}$} & for. & AGTCCCTGGGCTGGACTAAG & $267 \mathrm{bp}$ & $\begin{array}{l}\text { [GenBank: } \\
\text { NM_031680] }\end{array}$ \\
\hline & rev. & GTGTCTGACAATGCCAGGTG & & \\
\hline \multirow[t]{2}{*}{ HPRT1 } & for. & TCCCAGCGTCGTGATTAGTG & $225 \mathrm{bp}$ & $\begin{array}{l}\text { [GenBank: } \\
\text { NM_012583] }\end{array}$ \\
\hline & rev. & CAAAGAA & & \\
\hline
\end{tabular}

Sequences for forward (for.) and reverse (rev.) primers are given in $5^{\prime} \rightarrow 3^{\prime}$ order.
Table 2 Mouse primer sequences used in the study

\begin{tabular}{|c|c|c|c|c|}
\hline Target & & Sequence & Length & Accession No. \\
\hline \multirow[t]{2}{*}{$\begin{array}{c}\text { nAChR } \\
\alpha 7\end{array}$} & for & ACAATACTTCGCCAGCACCA & $144 \mathrm{bp}$ & $\begin{array}{l}\text { [GenBank: } \\
\text { AF225980] }\end{array}$ \\
\hline & rev & AAACCATGCACACCAGTTCA & & \\
\hline \multirow[t]{2}{*}{$\begin{array}{c}\text { nAChR } \\
\alpha 9\end{array}$} & for & CAATGCTCTGCGTCCAGTAG & 209 bp & $\begin{array}{c}\text { [GenBank: } \\
\text { XM_132045] }\end{array}$ \\
\hline & rev & ACACCAGATCGCTGGGAATC & & \\
\hline \multirow[t]{2}{*}{$\begin{array}{l}\text { nAChR } \\
\alpha 10\end{array}$} & for & TCTGCTCCTGCTCTITCTCC & 208 bp & $\begin{array}{l}\text { [GenBank: } \\
\text { XM_89067] }\end{array}$ \\
\hline & rev & CCACAGGTACAAGGTCAGCA & & \\
\hline \multirow[t]{2}{*}{$\begin{array}{c}\text { nAChR } \\
\beta 2\end{array}$} & for & GAGTGTGAGGGAGGATTGGA & 139 bp & $\begin{array}{l}\text { [GenBank: } \\
\text { AY574268] }\end{array}$ \\
\hline & rev & TCGTGGCAGTGTAGTTCTGG & & \\
\hline \multirow[t]{2}{*}{$\begin{array}{c}\text { nAChR } \\
\beta 4\end{array}$} & for & CAGCCCATCCAACCTCTATG & 156 bp & $\begin{array}{l}\text { [GenBank: } \\
\text { NM_148944] }\end{array}$ \\
\hline & rev & CTGACGCCCTCTAATGCTTC & & \\
\hline \multirow[t]{2}{*}{$\beta-M G$} & for & ACCCTGGTCTTTCTGGTGCT & 150 bp & $\begin{array}{l}\text { [GenBank: } \\
\text { NM_009735] }\end{array}$ \\
\hline & rev & AATGTGAGGCGGGTGGAA & & \\
\hline
\end{tabular}

performed by omitting the reverse transcription step or using water instead of cDNA template.

Differences were noted for two methods used to prepare cDNA. Successful detection of rat $\alpha 9$ subunit mRNA required reverse transcription with Superscript II system. Amplification of rat $\alpha 9$ subunit mRNA from BAL cDNA generated with iScript enzyme was not successful. This may be due to different priming strategies (oligo $(\mathrm{dT})$ and blend of oligo $(\mathrm{dT})+$ random hexamer primers, respectively) or to reduced RNAse $\mathrm{H}$ activity in SuperScriptII enzyme, which enables more efficient cDNA synthesis [13].

\section{Immunofluorescence}

Lavaged rat cells ( $\mathrm{n}=10$ animals) were plated on polystyrene 8-well culture slides (BD Biosciences, Erembodegem, Belgium) in DMEM/F12 supplemented with penicillin $(100 \mathrm{U} / \mathrm{ml})$ and streptomycin $(0.1 \mathrm{mg} / \mathrm{ml})$. Cells were allowed to attach for $2 \mathrm{~h}$, and then fixed in acetone $\left(-20^{\circ} \mathrm{C}, 10 \mathrm{~min}\right)$ or isopropanol $\left(+4^{\circ} \mathrm{C}, 10 \mathrm{~min}\right)$ and air-dried for $1 \mathrm{~h}$.

Shock-frozen rat lung specimens were prepared as described previously [14]. Cryostat sections were cut at $10 \mu \mathrm{m}$ thickness, fixed as above and subjected to indirect immunofluorescence using antisera directed against nAChR subunits and monoclonal antibody ED1, directed to a CD68-like antigen expressed by rat AM [15] (Serotec, Düsseldorf, Germany) (Table. 3). Briefly, unspecific binding sites were saturated with 50\% normal horse serum in PBS for $1 \mathrm{~h}$, followed by overnight incubation with the primary antibody, washing $(3 \times 10 \mathrm{~min})$ 
Table 3 Antibodies used in the study

\begin{tabular}{|c|c|c|c|c|}
\hline Target & Immunogen & Host & Dilution & Source \\
\hline $\mathrm{nAChR} \alpha 3$ & Synthetic peptide (aa $466-474$ of human sequence) ${ }^{a}$ & Rabbit & $1: 1600$ & Acris \\
\hline $\mathrm{nAChR} \alpha 4$ & Synthetic peptide (620-627, human) ${ }^{a}$ & Rabbit & $1: 800$ & Acris \\
\hline nAChR $\alpha 5$ & Synthetic peptide (460-468, human) ${ }^{a}$ & Rabbit & $1: 1600$ & Acris \\
\hline nAChR $\alpha 7$ & Synthetic peptide (493-502, human) ${ }^{a}$ & Rabbit & $1: 1000$ & Acris \\
\hline nAChR $\alpha 7$ & $\begin{array}{l}\text { Native and denatured } \alpha 7 \text { subunit (380-400, chicken) and denatured } \alpha 7 \\
\text { subunit from rat }\end{array}$ & $\begin{array}{l}\text { Mouse, monoclonal, clone } \\
\text { mAb } 306\end{array}$ & $1: 750$ & $\begin{array}{l}\text { Sigma- } \\
\text { Aldrich }\end{array}$ \\
\hline $\mathrm{nAChR} \alpha 9$ & Synthetic peptides (81-97 and 115-128, rat) & Guinea-pig & $1: 1000$ & [44] \\
\hline $\mathrm{nAChR} \alpha 10$ & Synthetic peptide $(404-418, \text { rat })^{a}$ & Rabbit & $1: 2000$ & [17] \\
\hline $\mathrm{nAChR} \beta 2$ & Synthetic peptide (493-502, human) ${ }^{a}$ & Rabbit & $1: 1600$ & Acris \\
\hline $\mathrm{nAChR} \beta 3$ & Synthetic peptide $\left(450-458\right.$, human $^{a}$ & Rabbit & 1:800 & Acris \\
\hline $\mathrm{nAChR} \beta 4$ & Synthetic peptide (490-498, human) ${ }^{a}$ & Rabbit & $1: 3200$ & Acris \\
\hline CD68-like & Rat spleen cells & Mouse, monoclonal, clone ED1 & 1:800 & Serotec \\
\hline $\begin{array}{l}\text { pSTAT3 } \\
\text { Tyr705 }\end{array}$ & Synthetic phospho-peptide residues surrounding Tyr705 of mouse Stat3 & $\begin{array}{l}\text { Rabbit, monoclonal, clone } \\
\text { D3A7 }\end{array}$ & $1: 1000$ & $\begin{array}{l}\text { Cell } \\
\text { Signaling }\end{array}$ \\
\hline $\begin{array}{l}\text { pSTAT3 } \\
\text { Ser727 }\end{array}$ & Synthetic phospho-peptide residues surrounding Ser 727 of mouse Stat 3 & Rabbit, monoclonal & $1: 1000$ & $\begin{array}{l}\text { Cell } \\
\text { Signaling }\end{array}$ \\
\hline STAT3 & Synthetic peptide corresponding to the sequence of mouse Stat3 & Rabbit, monoclonal & $1: 1000$ & $\begin{array}{l}\text { Cell } \\
\text { Signaling }\end{array}$ \\
\hline
\end{tabular}

Origin and regions of $\mathrm{nAChR}$ subunits sequences used for generation of the antibodies are provided in brackets. ${ }^{\mathrm{a}}$ Peptides available for preabsorption.

and application of secondary antibody for $1 \mathrm{~h}$. Slides were washed, fixed in buffered $4 \%$ paraformaldehyde, coverslipped in carbonate-buffered glycerol $(\mathrm{pH}$ 8.6) and examined with a Zeiss Axioplan 2 microscope (Zeiss, Jena, Germany) and sequential confocal laser scanning microscope (CLSM, TCS SP2, Leica, Bensheim, Germany) using argon and $\mathrm{HeNe}$ lasers equipped with appropriate filter sets. Secondary antisera were Cy3-coupled donkey anti-rabbit IgG (1:2000 in PBS, Chemicon, Hofheim, Germany), Cy3-coupled donkey anti-guinea pig IgG (1:800 in PBS, Dianova, Hamburg, Germany), fluorescein-isothiocyanate-conjugated donkey anti-mouse Ig (1:400, Dianova), and Texas Red $^{\circ}$-conjugated donkey anti-guinea pig Ig (1:100, Dianova). Positive controls were run on shock-frozen and acetonefixed DRG sections. The specificity of the immunolabeling was validated by omission of the primary antibody or preincubation with the corresponding antigen. Preabsorption was done by mixing antibodies with peptide used for immunization (14-24 $\mu \mathrm{g}$ of peptide per $100 \mu \mathrm{l}$ of antibody solution) for $1 \mathrm{~h}$ before application on slides. Peptides were obtained from the same source as the antibodies (Table. 3 ).

\section{SDS-PAGE and immunoblotting $n A C h R \alpha 7$ and $\alpha 10$ subunits detection}

Snap-frozen rat BAL cells, rat brain and skin samples were homogenized and boiled in Laemmli's sample buffer [16] containing Complete ${ }^{\curvearrowleft}$ protease inhibitor cocktail (Roche, Mannheim, Germany). SDS-PAGE was carried out using $15 \%$ polyacrylamide gels according to Laemmli et al. [16]. Samples $\left(5 \times 10^{4}\right.$ cells $)$ and Rainbow ${ }^{\mathrm{Tm}}$ colored molecular mass markers (Amersham Pharmacia Biotech, Freiburg, Germany) were separated on the same gel. Proteins were transferred electrophoretically onto Immobilon $^{\text {TM }}$-P PVDF membranes (Millipore, Bedford, USA) using a blotting buffer consisting of $25 \mathrm{mM}$ Tris, $192 \mathrm{mM}$ glycine, 20\% methanol and 0.05\% SDS. Membranes were pre-incubated with PBS containing $10 \%$ Rotiblock (Roth, Karlsruhe, Germany) solution for $1 \mathrm{~h}$. Primary mouse-anti-nAChR $\alpha 7$ (1:1000, Sigma-Aldrich, Taufkirchen, Germany) antibodies were diluted in blocking solution and incubated with membranes overnight at $4^{\circ} \mathrm{C}$. For the detection of $\alpha 10$ subunits, membranes were pre-incubated with PBS containing 5\% non-fat milk powder (Roth) and guinea pig-anti-nAChR $\alpha 10$ (1:4000, [17]) antibodies were used. Blots were washed in PBS, $0.05 \%$ Tween 20 and bound primary antibodies were detected by horseradish peroxidase-conjugated immunoglobulins (DAKO, Hamburg, Germany) in PBS, 2\% low fat milk, $0.05 \%$ Tween 20 (TPBS). Secondary antisera were rabbit anti-mouse IgG (1:5000 in TPBS $+1 \%$ normal rat serum) and rabbit-anti-guinea pig IgG (1:5000 in TPBS $+2 \%$ low fat milk). Peroxidase activity was visualized by SuperSignal ${ }^{\circ}$ West Pico Chemiluminescent Substrate (Pierce, Rockford, IL, USA) using the Kodak Scientific Imaging Film X-OMAT ${ }^{\mathrm{Tm}}$ LS (Eastman Kodak, Rochester, NY, USA). Gels and blots were documented and densitometrically analyzed using a digital gel documentation system (Biozym, Hessisch Oldendorf, Germany).

\section{STAT3 phosphorylation}

Lavaged rat cells were plated on a 24 well plate (Becton Dickinson, USA) at $3.5 \times 10^{5}$ cells/well in RPMI 1640 
medium supplemented with L-glutamine, penicillin (100 $\mathrm{U} / \mathrm{ml})$ and streptomycin $(0.1 \mathrm{mg} / \mathrm{ml})$. Cells were allowed to attach for $2 \mathrm{~h}$ and subsequently were stimulated with nicotine (Sigma-Aldrich) at $10^{-4} \mathrm{M}, 10^{-5} \mathrm{M}$, and $10^{-6} \mathrm{M}$ or GM-CSF (R\&D Systems, Minneapolis, MN) at 100 $\mathrm{ng} / \mathrm{ml}$ for indicated time intervals. Cells were washed twice with cold PBS and lysed with lysis buffer containing $20 \mathrm{mM}$ Tris (pH 7.5), $150 \mathrm{mM} \mathrm{NaCl}, 1 \mathrm{mM}$ EDTA (pH 8.0), 1 mM EGTA (pH 8.0), 0.5\% NP-40, 2 mM sodium orthovanadate ( $\mathrm{pH} 10.0)$, and Complete ${ }^{\circ}$ protease inhibitor cocktail (Roche). The lysates were kept on ice for $30 \mathrm{~min}$, followed by centrifugation for $15 \mathrm{~min}$ at $13,000 \mathrm{rpm}$ at $4^{\circ} \mathrm{C}$, and subsequent protein concentration measurement was assessed by Bradford Assay as suggested by the manufacturer (Bio-Rad). Proteins were loaded on a gel in a total amount of $10 \mu \mathrm{g}$, separated by electrophoresis on $10 \%$ SDS-PAGE, and transferred to polyvinylidene difluoride membranes (Amersham GE Healthcare, Little Chalfont, Buckinghamshire, UK). Membranes were incubated in blocking buffer (5\% nonfat milk in PBS, $0.05 \%$ Tween 20) at room temperature for $1 \mathrm{~h}$, and then overnight at $4^{\circ} \mathrm{C}$ with primary antibodies recognizing total and phosphorylated STAT3 (1:1000, Cell Signaling Technology, Beverly, MA). Blots were washed three times for $15 \mathrm{~min}$, and incubated with horseradish peroxidase-conjugated anti-rabbit IgG (1:3500, Pierce, Rockford, IL). Enhanced chemiluminescence system was used to visualize immune complexes (Amersham GE Healthcare, Little Chalfont, Buckinghamshire, UK).

\section{Electrophysiological recording}

For whole cell patch-clamp recordings, $200 \mu \mathrm{l}$ cell suspension obtained from rat BAL was placed in recording dishes (Nunc, Roskilde, Denmark), incubated for 1-3 h at $37^{\circ} \mathrm{C}$ and $5 \% \mathrm{CO}_{2}$ in DMEM/F12 medium to allow the cells to attach. PC12 cells (rat adrenal pheochromocytoma cells) were obtained from German Collection of Microorganisms and Cell Cultures (Braunschweig, Germany) and maintained at $37^{\circ} \mathrm{C}$ and $5 \% \mathrm{CO}_{2}$ in RPMI 1640 medium supplemented with $10 \%$ horse serum (PAA), 5\% FCS, 2 mM L-glutamine, penicillin (100 U/ $\mathrm{ml})$, streptomycin $(0.1 \mathrm{mg} / \mathrm{ml})$ and used as described above.

For recordings, the medium was carefully removed, cells were washed 2-3 times, covered with bath solution containing (in mM): $\mathrm{NaCl} 120, \mathrm{KCl} 5.4, \mathrm{CaCl}_{2} 2, \mathrm{MgCl}_{2}$ 1, Hepes 10, D-glucose 25, pH 7.5, and the dish was placed under a microscope (Axiovert, Göttingen, Germany).

Borosilicate glass capillaries (Hilgenberg, Malsfeld, Germany) with an outer diameter of $1.6 \mathrm{~mm}$ were pulled to recording pipettes by a vertical puller (Narishige, Tokyo, Japan). The tips of the pipettes were fire- polished using a microforge (List-Medical, Darmstadt, Germany) and had resistances between 5-10 $\mathrm{M} \Omega$ when filled with the pipette solution containing (in $\mathrm{mM}$ ): $\mathrm{KCl}$ 120, $\mathrm{CaCl}_{2} 1, \mathrm{MgCl}_{2}$ 2, Hepes 10, EGTA 11, D-glucose 20, $\mathrm{pH}$ 7.3. The junction potential under these conditions (bath and pipette solution) was $3.4 \mathrm{mV}$ although the membrane voltage was not corrected with respect to this junction potential.

The whole cell configuration was mainly obtained by suction and in some cases voltage pulse was additionally applied. Transmembrane currents were recorded at holding potentials of $-60 \mathrm{mV}$ in the absence of, as well as after ACh application into the bath. The agonist was applied via a pipette to the bath to reach a final concentration of $100 \mu \mathrm{M}$. In some experiments, a VM-4 micro-perfusion system was used for drug compound application (ALA Scientific Instruments, Westbury, USA). The measured signals were amplified by an EPC9 patch-clamp amplifier (HEKA, Lambrecht/Pfalz, Germany), which was connected via an ITC-16 interface to a personal computer. For continuous recordings, the signals were filtered with $300 \mathrm{~Hz}$ and acquired at $3 \mathrm{kHz}$ using the Pulse 8.77 software (HEKA). Current/voltage relationships signals were filtered with $3.33 \mathrm{kHz}$ and acquired at $10 \mathrm{kHz}$. Data ware analyzed and prepared using PulseFit (HEKA) and Igor (Wavemetrics, Lake Oswego, USA). All recordings were performed at room temperature.

\section{Intracellular calcium concentration measurements}

Recordings of $\left[\mathrm{Ca}^{2+}\right]_{\mathrm{i}}$ were performed after 3-8 $\mathrm{h}$ in primary culture ( $\mathrm{n}=3$ animals and 10-12 coverslips for each experimental setup). Measurements were done in Hepes buffer containing (in $\mathrm{mM}$ ): $\mathrm{KCl} 5.6, \mathrm{NaCl} 136.4$, $\mathrm{MgCl}_{2} 1, \mathrm{CaCl}_{2}$ 2.2, D-glucose 11, Hepes 10. In some experiments, $\mathrm{CaCl}_{2}$ was omitted from the buffer composition. Cells were loaded for $30 \mathrm{~min}$ with $3.3 \mu \mathrm{M}$ fura-2 AM (Invitrogen) and washed $3 \times 10 \mathrm{~min}$. Fura- 2 was excited at 340 and $380 \mathrm{~nm}$ wavelengths $(\lambda)$, and fluorescence was collected at $\lambda>420 \mathrm{~nm}$. The fluorescence intensity ratio of $340 / 380 \mathrm{~nm}$ was recorded. Cells were exposed to nicotine $\left(10^{-6}-10^{-4} \mathrm{M}\right.$, Sigma-Aldrich) or epibatidine $\left(10^{-6} \mathrm{M}\right.$, Sigma-Aldrich). Controls were performed with vehicle treatment. Two min after administration of nicotine or epibatidine, cells were stimulated with ATP $\left(10^{-4} \mathrm{M}\right.$, Sigma-Aldrich). In some experiments cells were exposed to nicotine in the presence of the nAChR $\alpha 7$ and $\alpha 9 / \alpha 10$ blocker $\alpha$-bungarotoxin $\left(10^{-7} \mathrm{M}\right.$, Sigma-Aldrich). Cells that did not respond to ATP by at least $5 \%$ change in $\left[\mathrm{Ca}^{2+}\right]_{i}$ were excluded from further analysis. Viability of the cells was monitored after measurements with Trypan Blue exclusion. Ratio values were normalized to $100 \%$ at the beginning of recording. Curves were plotted from recordings 
done in preparations from $\mathrm{n}=3$ animals. Data are shown as mean \pm SEM.

\section{Statistical analysis}

Data in the figures and text are expressed as mean \pm SEM. Non-parametric rank based Kruskal-Wallis test was used to compare multiple groups, and if significant differences were detected, it was followed by MannWhitney test to compare between two experimental groups. Tests were performed using SPSS software (SPSS software, Munich, Germany). P $\leq 0.05$ was considered significant and $\mathrm{P} \leq 0.01$ as highly significant.

\section{Results}

Rat alveolar macrophages constitutively express nAChR subunits $\alpha 9, \alpha 10$ and $\beta 2$, but not $\alpha 7$

RT-PCR analysis of mRNA isolated from rat BAL cells revealed expression of $\mathrm{nAChR}$ subunits $\alpha 2, \alpha 3, \alpha 5, \alpha 9$, $\alpha 10, \beta 1$, and $\beta 2$. Products corresponding to the $\alpha 4, \alpha 6$, $\alpha 7$, and $\beta 3$ subunits were never found in BAL cells (Fig. $1)$, although they were easily detectable in DRG and lung homogenate ( $\alpha 7$ and $\beta 3$ subunits). The mRNAs of subunits $\alpha 9, \alpha 10, \beta 1$, and $\beta 2$ were consistently expressed. Subunits $\alpha 2, \alpha 3$, and $\beta 4$ were detected in 1 out of 9 preparations. Subunit $\alpha 5$ was present in 3 out of 9 preparations. The identity of amplified products was confirmed by sequencing, and control runs without template were negative.

In indirect double-labeling immunofluorescence, the vast majority of rat BAL cells showed strong staining with ED1 antibody, an AM marker. ED1-positive cells were immunoreactive for $\alpha 9, \alpha 10$, and $\beta 2 \mathrm{nAChR}$ subunits, and in $50 \%$ of BAL preparations (5 out of 10 samples) for the $\alpha 5$ subunit as well. Preabsorption with the synthetic peptides used for immunization resulted in absence of immunolabeling (Fig. 2). Staining was predominantly intracellular, localized near the nucleus, except for $\alpha 5$ and $\alpha 9$ subunit-immunoreactivity that exhibited a punctate surface distribution in a subset of AM (Fig. 2, inserts). The rabbit polyclonal antibody to $\alpha 7$ subunit faintly stained AM, but preabsorption with corresponding peptide gave the same staining pattern. The monoclonal antibody to the $\alpha 7 \mathrm{nAChR}$ subunit (mAb 306) did not show any labeling of AM. Positive controls were run on DRG sections, demonstrating labeling of neuronal cell bodies with mAb 306 (Fig. 3). There was no specific labeling for subunits $\alpha 3, \alpha 4, \beta 3$, and $\beta 4$ in ED1-positive cells (Fig. 2 and data not shown). Similar staining patterns with antisera directed against $n A C h R$ subunits were observed in rat lung sections (Fig. 3). Here, the antiserum against the $\alpha 9 \mathrm{nAChR}$ subunit showed marked punctuate membrane staining of AM (Fig. 3, insert).

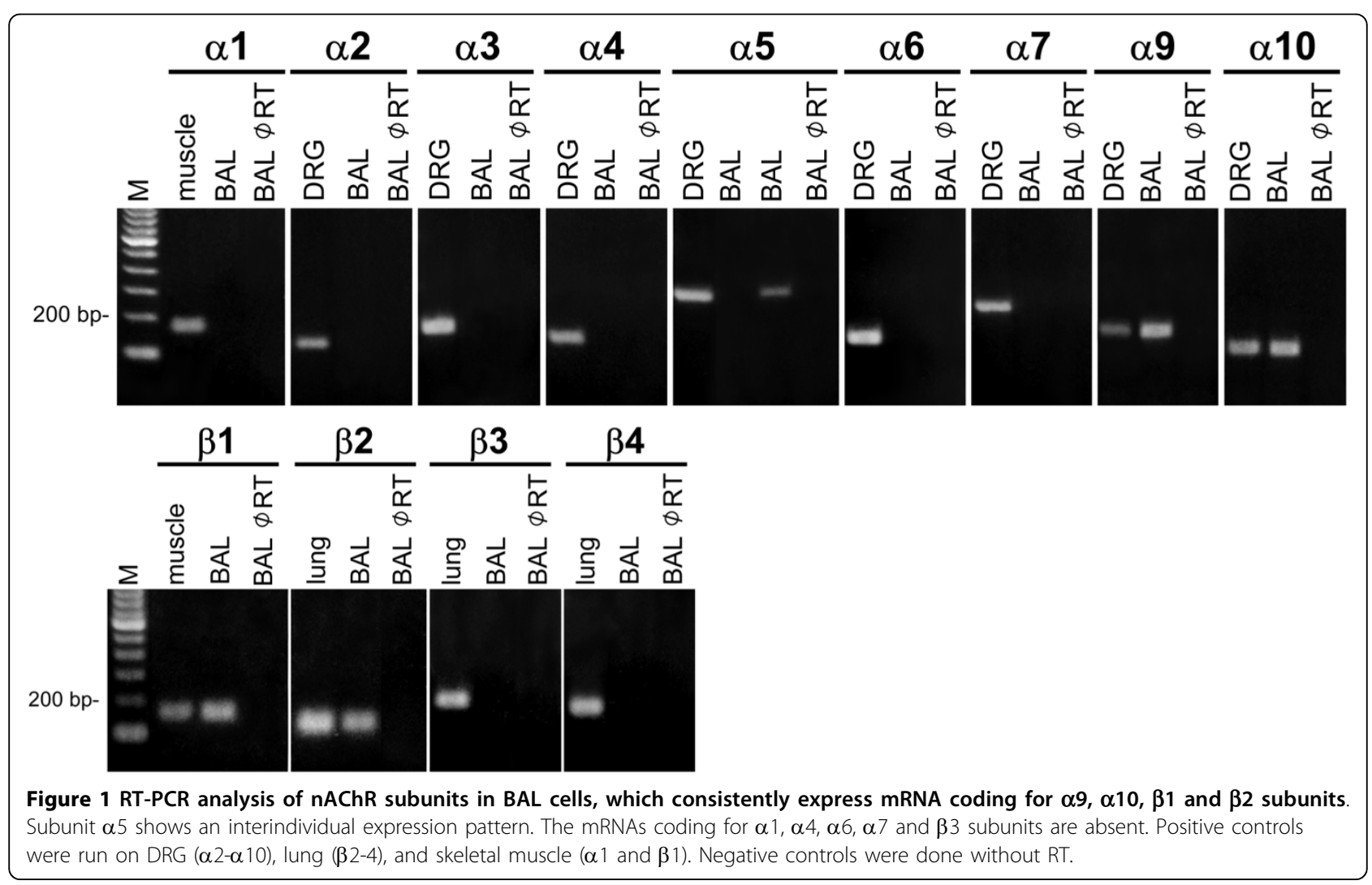




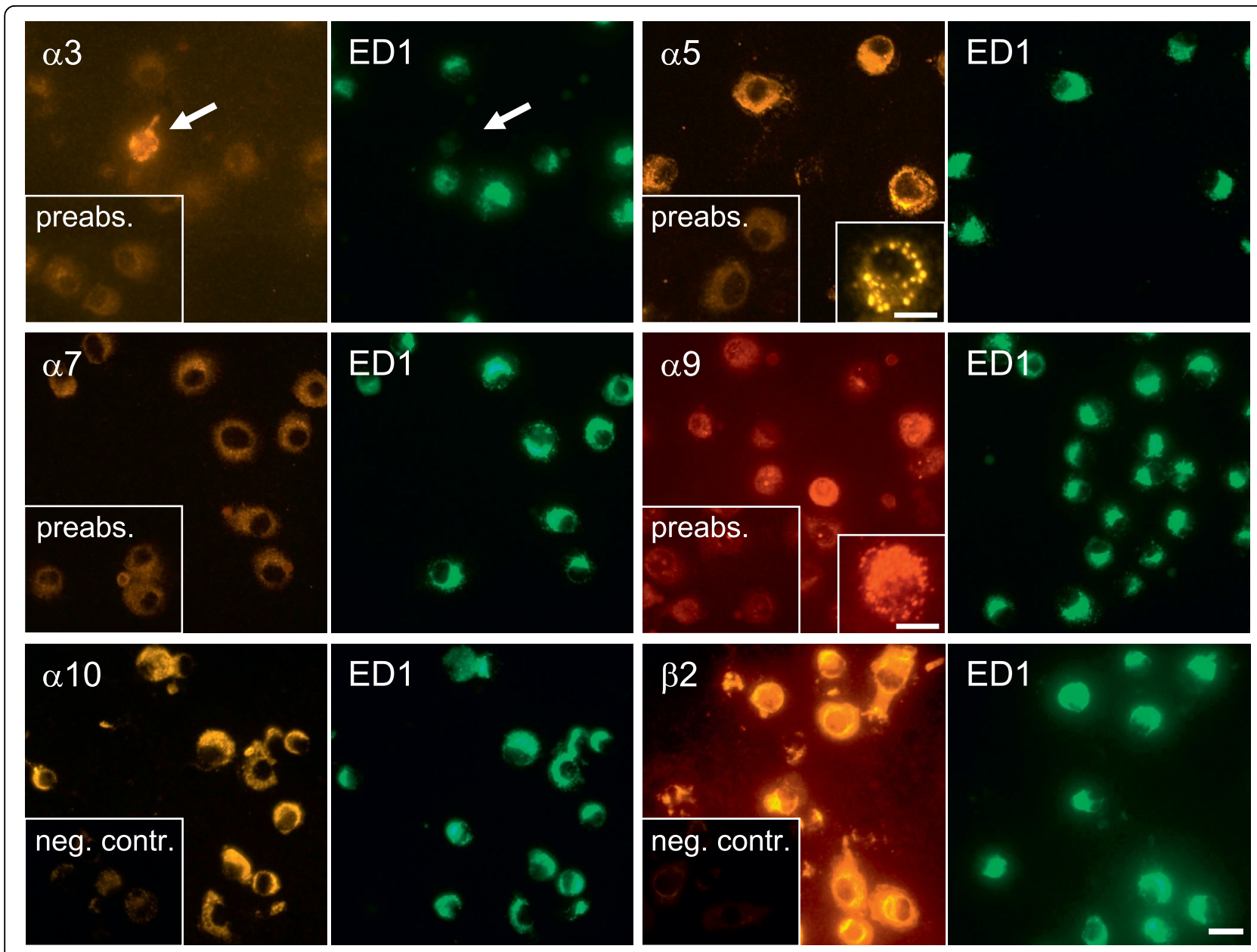

Figure 2 Double-labeling immunofluorescence demonstrating the presence of the nAChR subunits $\alpha 5, \alpha 9, \alpha 10$ and $\beta 2$ in ED1-positive BAL cells. A punctate fluorescence pattern for the $\alpha 5$ and $\alpha 9$ nAChR subunits was found in a subset of AM (inserts). Negative results were noted for $\alpha 3$ and $\alpha 7$ subunits in ED1-positive cells, despite occasional occurrence of $\alpha 3$ subunit immunoreactive ED1-negative cells (arrow). Bar: $20 \mu \mathrm{m}, 10 \mu \mathrm{m}$ in inserts.

Western blotting supported the immunohistochemical findings in that the mAb 306 failed to detect the $\alpha 7$ subunit in protein preparations from rat BAL cells while it recognized a $\sim 50 \mathrm{kDa}$ band in protein extracts from rat brain (Fig. 4). In Western blots of rat skin homogenates serving as a positive control, a single $67-\mathrm{kDa}$ protein was recognized utilizing a previously characterized antiserum directed against the $\alpha 10 \mathrm{nAChR}$ subunit [12]. As shown in Fig. 4, this band plus additional bands at $110-130 \mathrm{kDa}$ were immunolabeled in protein preparations from BAL cells.

\section{Acetylcholine has no effect on AM cell membrane conductivity}

Recordings were performed at $-60 \mathrm{mV}$ holding potential. ATP $\left(2 \times 10^{-4} \mathrm{M}\right)$ induced currents in approximately $50 \%$ of the recorded rat AM (Fig. 5A). Notably, no changes in membrane currents were detected when
ACh $\left(10^{-4} \mathrm{M}\right)$ was added to the bath (Fig. 5D, $\left.\mathrm{n}=15\right)$. In a separate set of recordings, ACh was applied via a perfusion system, again without triggering changes in transmembrane current $\left(\mathrm{I}_{\mathrm{M}}\right)$ (see insert of figure $5 \mathrm{D}$ ). In contrast, PC12 cells readily responded to ACh application by an increased inward current (Fig. 5C).

For further characterization of AM responses, I/V curves were recorded by applying voltage steps of 20 $\mathrm{mV}$ from -100 to $100 \mathrm{mV}$, starting from a holding potential of $-60 \mathrm{mV}$. I/V-relationships were also recorded in the absence (Fig. 5F) and presence of $\mathrm{ACh}$ (Fig. 5E). Again, no changes of $\mathrm{I}_{\mathrm{M}}$ were evoked by $\mathrm{ACh}$ application.

\section{ATP-triggered increase in calcium derives from} intracellular stores

In freshly isolated rat AM, ATP $\left(10^{-4} \mathrm{M}\right)$ induced a rapid rise in $\left[\mathrm{Ca}^{2+}\right]_{i}$ followed by a slow decrease. 

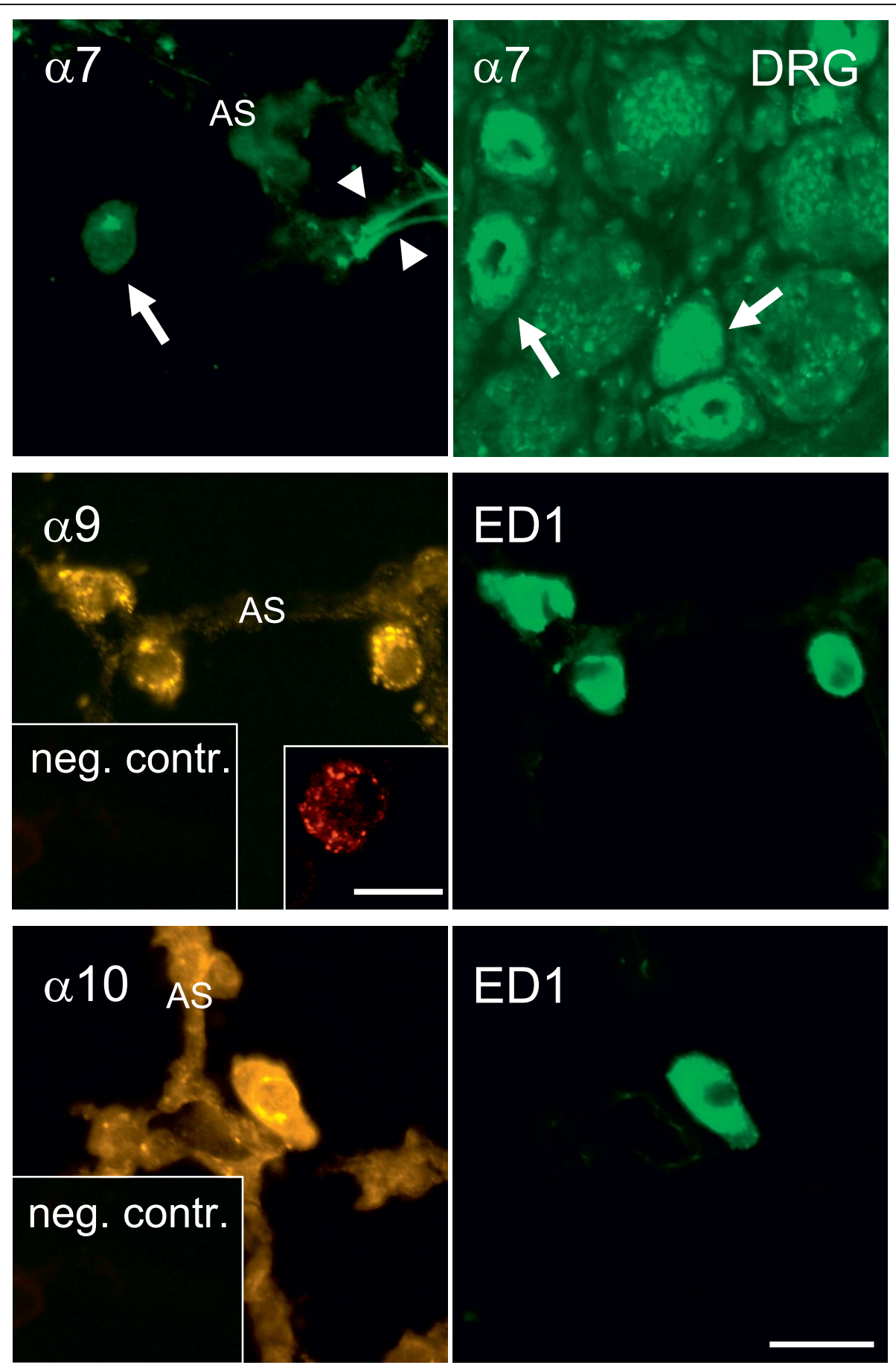

Figure 3 Immunohistochemistry on rat lung sections and DRG (positive control). The mAb 306 directed against the $\alpha 7$ subunit fails to label AM (arrow) but it stains nerve cell bodies (arrows) in DRG sections serving as a positive control. Arrowheads: Elastin autofluorescence in alveolus. The antibodies to $\alpha 9$ and $\alpha 10$ subunits label ED1-positive AM in alveoli. The insert demonstrates punctate $\alpha 9$ subunit immunoreactivity in a CLSM optical section. AS = alveolar septum. Bar: $20 \mu \mathrm{m}$.

Exclusion of calcium ions from the external solution had no effect on the amplitude of the ATP-induced initial $\left[\mathrm{Ca}^{2+}\right]_{\mathrm{i}}$ rise $\left(46 \%\right.$ for $+\mathrm{Ca}^{2+}$ and $47 \%$ for $-\mathrm{Ca}^{2+}$ Hepes buffer). Macrophages exposed to extracellular $\mathrm{Ca}^{2+}$ showed a sustained increase in $\left[\mathrm{Ca}^{2+}\right]_{\mathrm{i}}$ whereas cells stimulated in $\mathrm{Ca}^{2+}$-free buffer showed only a transient rise without reaching a plateau phase $(\mathrm{P} \leq 0.001)$ (Fig. 5A). The percentage of cells reacting to the ATP stimulus 


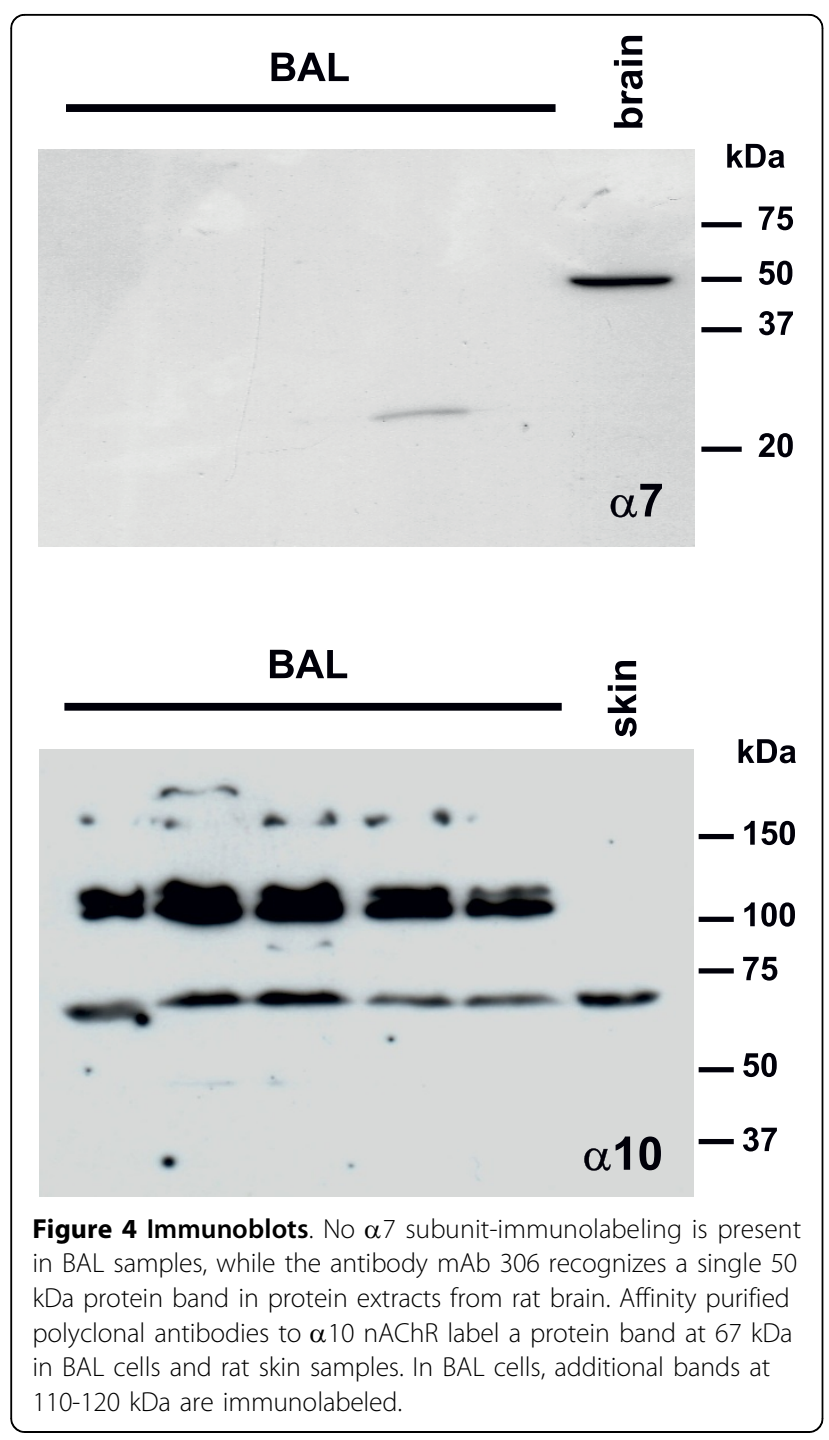

was decreased from $58 \%$ in calcium-containing to $18 \%$ in calcium-free buffer $\left(582 / 1012\right.$ cells in $+\mathrm{Ca}^{2+}$ vs $197 /$ 1085 cells in $-\mathrm{Ca}^{2+}$ buffer). To better understand which receptors might be involved in ATP-induced $\left[\mathrm{Ca}^{2+}\right]_{\mathrm{i}}$ rise we performed RT-PCR analysis and found $\mathrm{P}_{2} \mathrm{Y}_{1}, \mathrm{P}_{2} \mathrm{Y}_{2}$ and $\mathrm{P}_{2} \mathrm{Y}_{4}$ purinergic receptor mRNAs in AM (Fig. 6B).

Nicotine modulates ATP-induced rise in intracellular $\left[\mathrm{Ca}^{2+}\right]$ We tested whether nicotine modulates $\left[\mathrm{Ca}^{2+}\right]_{\mathrm{i}}$ levels. Half of the macrophage population (131/261 cells) exposed to ATP showed a transient rise in $\left[\mathrm{Ca}^{2+}\right]_{\mathrm{i}}$ (increase by $47 \%)$. Application of nicotine $\left(10^{-6}, 10^{-5}\right.$, $\left.10^{-4} \mathrm{M}\right)$ or epibatidine $\left(10^{-6} \mathrm{M}\right)$ had no direct effect on $\left[\mathrm{Ca}^{2+}\right]_{\mathrm{i}}$. Nicotine given $2 \mathrm{~min}$ prior to ATP reduced the ATP-induced calcium peak by $38 \%(\mathrm{P} \leq 0.006)$, while not changing the percentage of cells reacting to the ATP stimulus (54\%, 120/222 cells). Epibatidine was neither effective in reducing ATP-induced transients nor it changed the percentage of cells reacting to the ATP (51\%, 117/230 cells) (Fig. 7A).

In a separate set of experiments, we tested if the effect of nicotine can be blocked with the $\alpha 1, \alpha 7$ and $\alpha 9 / \alpha 9 \alpha 10 \mathrm{nAChR}$ antagonist $\alpha$-bungarotoxin. This drug alone $\left(10^{-7} \mathrm{M}\right)$ had no effect on ATP-induced calcium increase, when compared to vehicle control, but it abrogated the effects of nicotine $(\mathrm{P} \leq 0.001)$. The transient rise in $\left[\mathrm{Ca}^{2+}\right]_{i}$ in cells treated with $\alpha$ bungarotoxin together with nicotine was slightly increased compared to vehicle-treated cells $(\mathrm{P} \leq 0.025)$ (Fig. 7B).

We used AM isolated from $\alpha 7 \mathrm{nAChR}$-deficient mice to determine the role of this subunit in cholinergic modulation of ATP-induced $\mathrm{Ca}^{2+}$ response. Cells isolated by BAL from C57BL6N mice expressed mRNAs corresponding to $\alpha 9, \beta 2$ and $\beta 4 \mathrm{nAChR}$ subunits (Fig. $8 \mathrm{~A})$. Messenger RNA for the $\alpha 10$ subunit was found in 3 out of 5 samples, while $\alpha 7 \mathrm{nAChR}$ subunit mRNA was never detected in BAL cells. Pretreatment with nicotine significantly attenuated the transient rise in $\left[\mathrm{Ca}^{2+}\right]_{\mathrm{i}}$ triggered by ATP in BAL cells isolated from C57BL6N and $\alpha 7 \mathrm{nAChR}$-deficient mice (Fig. 8B), albeit the reduction was much less pronounced than in rat cells.

\section{Nicotinic modulation is not dependent on extracellular calcium}

Next we tested if the nicotine-mediated effect upon the ATP-induced $\left[\mathrm{Ca}^{2+}\right]_{\mathrm{i}}$ rise is depended on extracellular calcium. Rat cells treated with nicotine $\left(10^{-4} \mathrm{M}\right) 2 \mathrm{~min}$ before the ATP stimulus showed a decreased amplitude of the ATP-induced rise in $\left[\mathrm{Ca}^{2+}\right]_{\mathrm{i}}$. This was not affected by the absence of $\mathrm{Ca}^{2+}$ in the external bath solution (Fig. 7B). The number of cells reacting to ATP was reduced when $\mathrm{Ca}^{2+}$ was omitted in the external solution (18\% for vehicle and $16 \%$ for nicotine treated cells) compared to $\mathrm{Ca}^{2+}$-supplemented medium (42\% for vehicle and $39 \%$ for nicotine treated cells).

\section{Nicotine does not induce STAT-3 phosphorylation}

To test whether nicotinic stimulation of BAL cells triggers STAT-3 phosphorylation, as it has been reported for peritoneal macrophages [3], Western blot analysis was performed. Rat BAL cells were exposed to $10^{-4}$, $10^{-5}$, and $10^{-6} \mathrm{M}$ nicotine or to $100 \mathrm{ng} / \mathrm{ml} \mathrm{GM-CSF}$ serving as a positive control. No visible STAT-3 phosphorylation on Tyr705 epitope was observed in nicotine treated samples 5, 15, 30 and 60 min after stimulation. Similar results were obtained with an antibody recognizing phosphorylation of Ser727 epitope (data not shown). In contrast to nicotine, GM-CSF caused profound STAT-3 phosphorylation as soon as 5 min after addition to the cells (Fig. 9). 

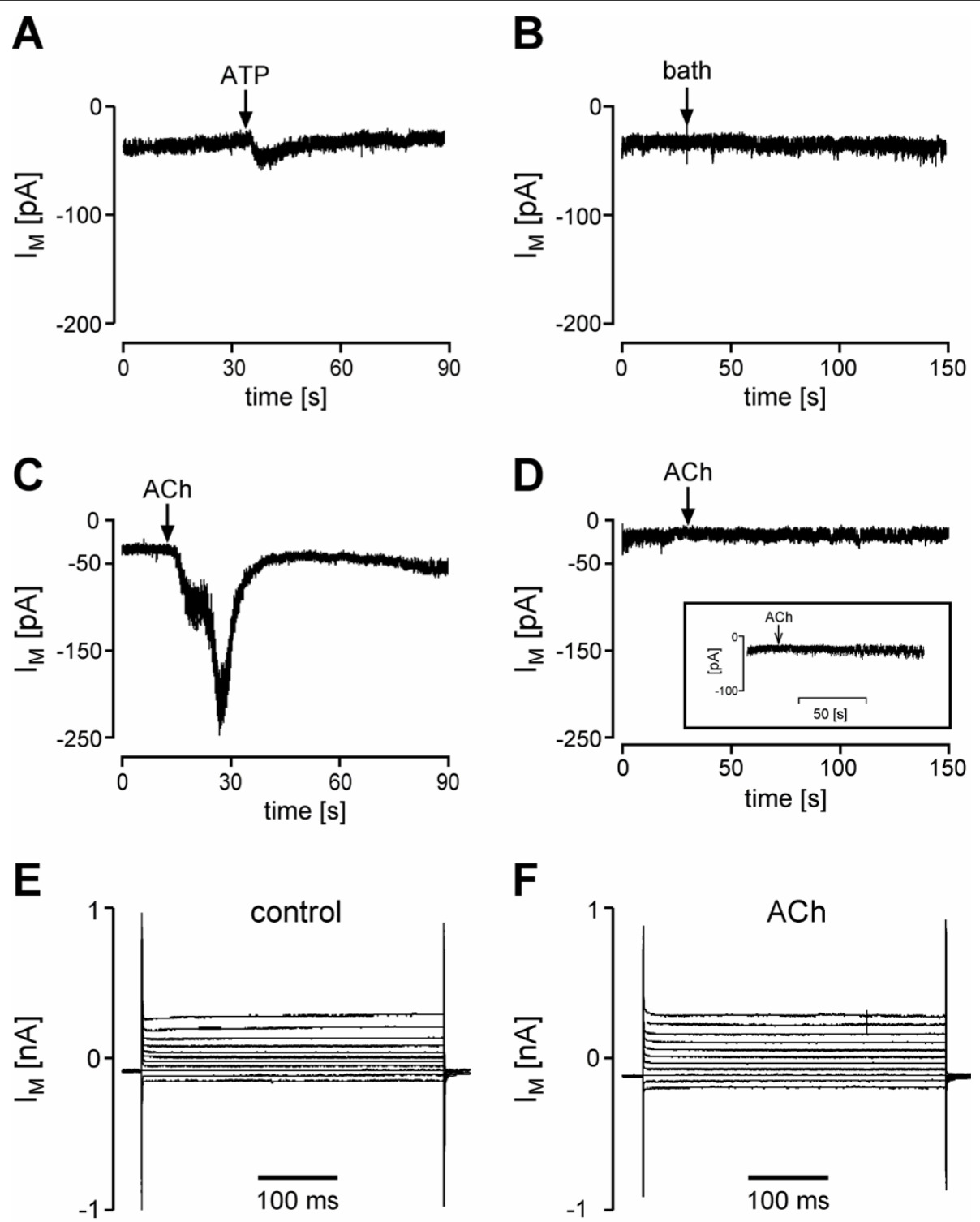

Figure 5 Patch clamp recordings on AM (A, B, D-F) and on PC12 cells (C). (A) Representative whole cell recording depicting the measured membrane current $\left(I_{M}\right)$ at -60 mV in absence of and following ATP application $\left(2 \times 10^{-4} \mathrm{M}\right.$, indicated by arrow). Agonist was applied directly to the bath via a pipette. ATP activates transient inward currents. (B) Control recording where bath solution was applied instead of agonist. (C) Effect of ACh (10-4 M) on PC12 cells. ACh induces strong inward currents. (D) Application of ACh to the bath solution has no effect on membrane currents in AM. Insert: The use of a perfusion system also did not induce any significant changes of the membrane current in response to $\mathrm{ACh}$. $(\mathrm{E}, \mathrm{F})$ Current-voltage relationship recorded in the absence of (control, E) and immediately after ACh application (F). In these recordings, again no changes in membrane current were detected.

\section{Discussion}

This study is the first to demonstrate acute receptordependent, modulatory effects of nicotine on AM. The nAChR involved in this process differ from subtypes reported previously to be involved in "cholinergic antiinflammatory pathways" outside the lung. Although the effects of nicotine are receptor mediated, these receptors do not form a classical ion channel known from neuronal cells.
Importantly, we detected neither mRNA nor protein of $\alpha 7 \mathrm{nAChR}$ in AM in contrast to easily detectable $\alpha 7$ subunit mRNA in sensory neurons, brain and in the whole lung homogenate. This is consistent with reported data on the lack of the expression of $\alpha 7$ nAChR in the murine AM cell line MH-S [18] and our previous work on expression of nAChR in freshly isolated murine AM [19]. In contrast, binding of the polyclonal nAChR $\alpha 7$ antibody $\mathrm{H}-320$ to murine AM has 

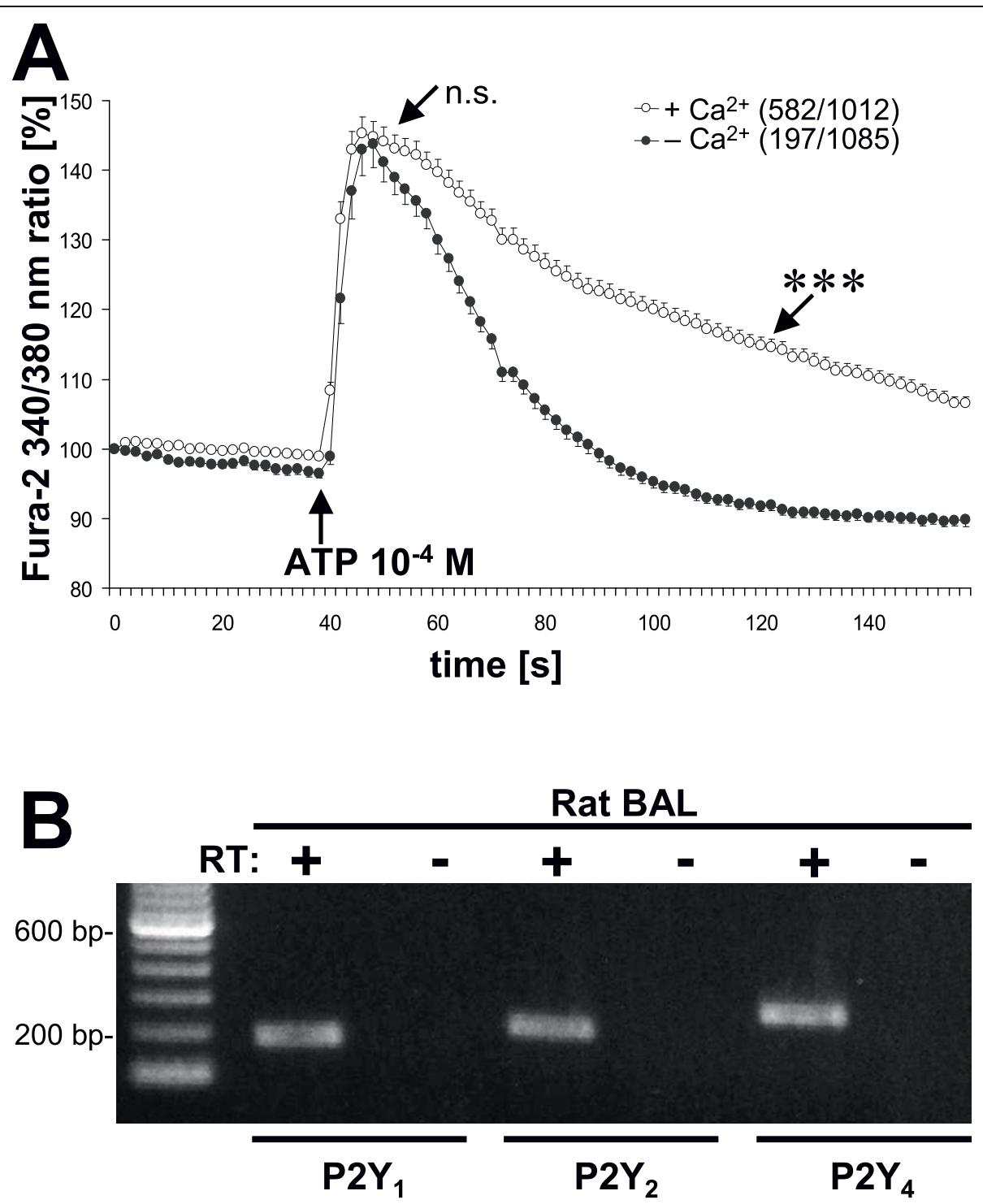

Figure 6 Purinergic receptors on freshly isolated BAL cells. ATP-induced transients in $\left[\mathrm{Ca}^{2+}\right]_{j}$ are mainly dependent on intracellular stores. (A) BAL cells were stimulated with ATP $\left(10^{-4} \mathrm{M}\right)$ in the presence or absence of extracellular $\mathrm{Ca}^{2+}$. Sustained increase, but not initial rise in $\left[\mathrm{Ca}^{2+}\right]_{\mathrm{i}}$ is dependent on extracellular $\mathrm{Ca}^{2+}$. Number of cells which reacted, and total number of measured cells are given in brackets. n.s. = not significant, ***P $\leq$ 0.001. (B) RT-PCR in rat BAL cells shows expression of $P 2 Y_{1}, P 2 Y_{2}$ and $P 2 Y_{4}$ purinergic receptors.

been reported by $\mathrm{Su}$ et al. $[8,9]$ and was also noted by our group in a previous study in the absence of $\alpha 7$ subunit mRNA detection [19]. This antibody, however, produces identical staining in immunohistochemistry and western blotting of the mouse brain, clearly demonstrating lack of specificity at least in the nervous system [20], so that these findings have to be considered with caution unless corresponding controls on mouse lungs from $\alpha 7 \mathrm{nAChR}^{-1-}$ mice have been successfully performed.

Still, there might be species differences and plasticity in receptor expression under pathological conditions, since a low level of basal expression of $\alpha 7 \mathrm{nAChR}$ subunit mRNA in AM isolated from healthy volunteers and an increase in AM isolated from smokers has been reported [21]. Also, $\alpha 7 \mathrm{nAChR}$ are essential for systemic cholinergic anti-inflammation since the beneficial effects of nicotine in endotoxemia are abrogated in $\alpha 7$ subunit gene-deficient mice [2]. Accordingly, two potent $\alpha 7$ nAChR agonists, GTS-21 and PNU-282987 [22,23], inhibit LPS-induced TNF $\alpha$ release and reduce acid-induced acute lung injury, respectively, in the mouse lung $[8,10]$. Their potency on the most prevalent $\mathrm{nAChR}$ subunits identified in our present study on AM, i.e. $\alpha 9$ and $\alpha 10$ $\mathrm{nAChR}$ that generally share many pharmacological properties with $\alpha 7 \mathrm{nAChR}$ [24], yet has not been 


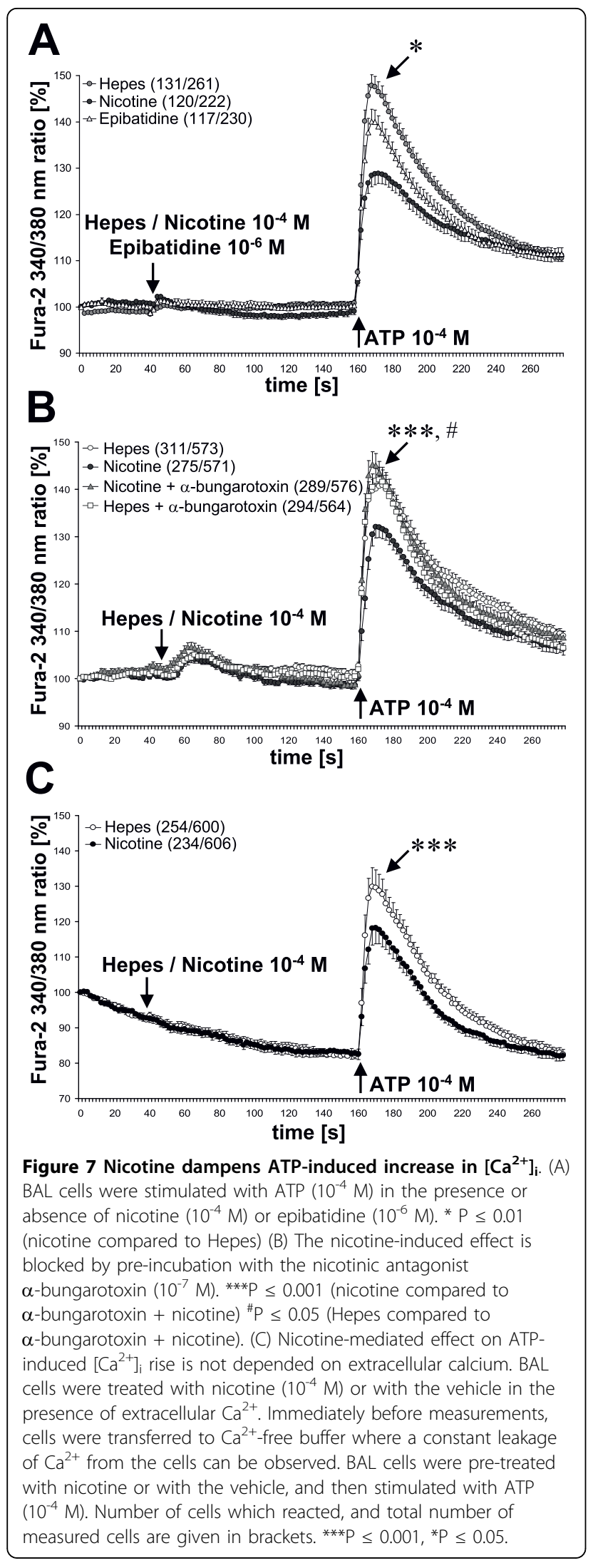

determined. Without doubt, however, $\alpha 7 \mathrm{nAChR}$ is expressed in the lung as demonstrated by RT-PCR in this and previous studies $[25,26]$. Functional data show increases in acid-induced excess lung water and vascular permeability in $\alpha 7 \mathrm{nAChR}$ deficient mice [8]. Endothelial cells may account for this effect [27]. However, since all $\alpha 7 \mathrm{nAChR}$ antibodies tested so far produce immunohistochemical labeling also in organs taken from $\alpha 7$ nAChR deficient mice $[20,28]$, immunohistochemistry alone cannot decipher the cell-type specific $\alpha 7$-subunit distribution in the lung, and this issue remains to be solved.

Instead of $\alpha 7$ we observed expression of nAChR subunits $\alpha 9, \alpha 10, \beta 1$, and $\beta 2$, and to a variable extent $\alpha 2$, $\alpha 3, \alpha 5$, in rat AM. Mouse AM expressed nAChR subunits $\alpha 9, \alpha 10, \beta 2$, and $\beta 4$. To form classical, ion-conducting $\mathrm{nAChR}, \alpha$ subunits combine as heteropentamers with $\beta$ subunits or build $\alpha$ heteropentamers of $\alpha 9 \alpha 10$ and homopentamers of $\alpha 7$ and $\alpha 9$ (for review, see [29]). The subunits detected in AM in the present study would allow combining the following nAChR pentamers: $\alpha 3 \beta 2, \alpha 3 \alpha 5 \beta 2, \alpha 9 \alpha 10$, and $\alpha 9$ as homopentamer. Since there is a constant expression of subunits $\alpha 9$ and $\alpha 10$ in $\mathrm{AM}$, this combination as homo- or heteropentamer seems to be most likely, if pentamer formation occurs at all.

These subunits have been best characterized in the inner ear, where they form $\mathrm{Ca}^{2+}$-permeable ion channels involved in efferent modulation of hair cell function $[30,31]$. Our whole-cell patch clamp recordings and $\left[\mathrm{Ca}^{2+}\right]_{\mathrm{i}}$ measurements in rat $\mathrm{AM}$, however, neither revealed changes in membrane current in response to ACh nor in $\left[\mathrm{Ca}^{2+}\right]_{i}$ in response to nicotine. Similarly, a subpopulation of human T-lymphocytes expresses $\alpha 9$ and $\alpha 10 \mathrm{nAChR}$ subunits but fails to show transmembrane currents triggered by ACh [5], and nicotine does not cause alteration of $\left[\mathrm{Ca}^{2+}\right]_{i}$ in the rat AM cell line NR8383 [32] and in rat intravascular mononuclear leukocytes obtained from isogenic kidney transplants [7]. Thus, $\alpha 9 \alpha 10$ nAChR subunits apparently do not form classical ionotropic receptors in cells of the immune system. Still, $\alpha 9 \alpha 10 \mathrm{nAChR}$ subunits confer intracellular effects as our data demonstrate an acute $\alpha$-bungarotoxin sensitive modulatory effect of nicotine upon ATPinduced calcium release from intracellular stores. In general, although to a much smaller extent than in rat cells, this effect was also present in macrophages isolated from C57BL6N and $\alpha 7 \mathrm{nAChR}$ subunit deficient mice, demonstrating its independency from the $\alpha 7$ nAChR subunit. Similarly, we recently identified a methyllycaconitine sensitive modulatory effect of nicotine upon ATP-induced rise in $\left[\mathrm{Ca}^{2+}\right]_{\mathrm{i}}$ in rat mononuclear leukocytes obtained by vascular perfusion of 


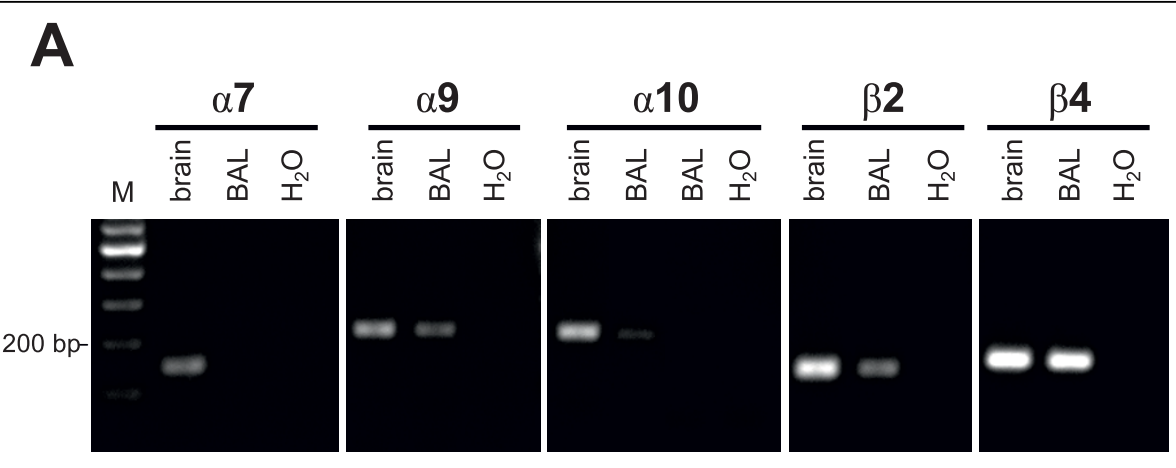

B

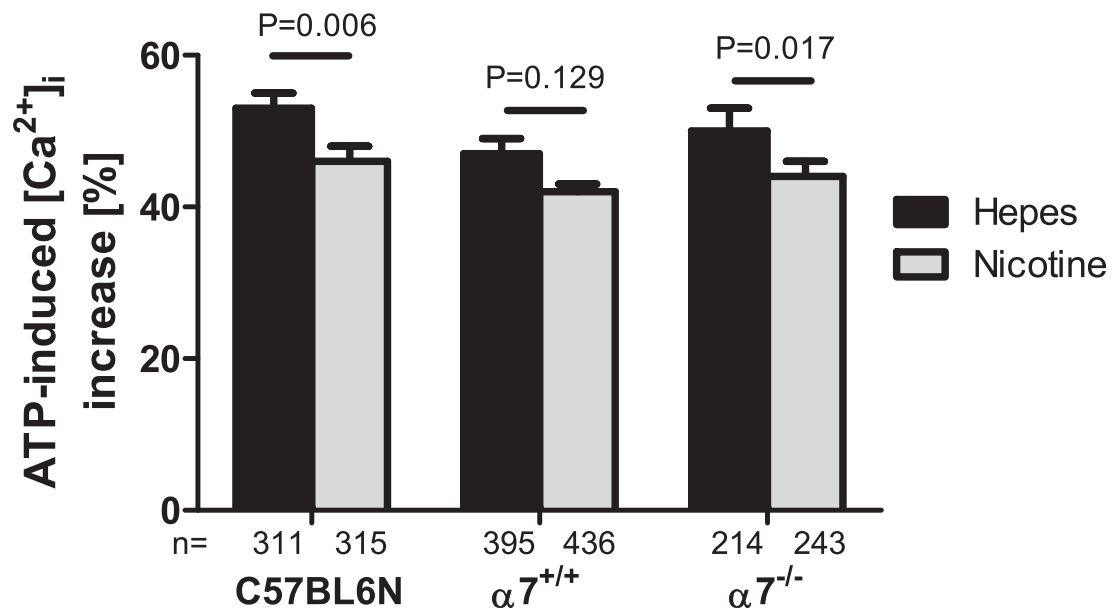

Figure 8 Nicotinic receptors on mouse BAL cells. (A) RT-PCR, agarose gel electrophoresis. Mouse BAL cells consistently express mRNAs coding for $\alpha 9, \beta 2$ and $\beta 4$ subunits. Subunit $\alpha 10$ shows an interindividual expression pattern. The mRNA for $\alpha 7$ subunit was not found in BAL preparations, although it was easily detectable in brain homogenate, serving as a positive control. $\mathrm{M}=\mathrm{DNA}$ marker, $\mathrm{H}_{2} \mathrm{O}=$ water control (B) Ratiometric $\left[\mathrm{Ca}^{2+}\right]_{\mathrm{i}}$ recordings. Mouse BAL cells isolated from C57BL6N, $\alpha 7$ nAChR knockout $\left(\alpha 7^{-1}\right)$ and littermate control animals $\left(\alpha 7^{+/+}\right)$were stimulated with ATP $\left(10^{-4} \mathrm{M}\right)$ in the presence or absence (Hepes) of nicotine $\left(10^{-4} \mathrm{M}\right)$. Peak increases shown as mean \pm SEM; cells taken from 6-9 coverslips for each experimental setup, p-values calculated by Mann-Whitney test.

isogenic kidney transplants [7]. In line with this observation, $\alpha 9$ subunit containing $\mathrm{nAChR}$ in outer hair cells of the inner ear do not exclusively assemble into ionotropic receptors, but form metabotropic receptors as well. Here, ACh also reduces ATP-induced rise in $\left[\mathrm{Ca}^{2+}\right]_{i}$ at a concentration that alone is insufficient to impact $\left[\mathrm{Ca}^{2+}\right]_{\mathrm{i}}$, and again this effect is $\alpha$-bungarotoxin sensitive [33].

Atypical, non-ionotropic effects have also been reported for the nAChR $\alpha 7$ subunit. In T cells, this subunit fails to form a ligand-gated $\mathrm{Ca}^{2+}$ channel but interacts with $\mathrm{CD} 3 \zeta$ to modulate TCR/CD3 function [6]. Notably, $\alpha 7$ subunits in this complex exhibit a different agonist/antagonists profile than neuronal ionotropic $\alpha 7$ nAChR. Methyllycaconitine and $\alpha$-bungarotoxin, both potent inhibitors of ionotropic $\alpha 7 \mathrm{nAChR}$, indeed are strong agonists at $\mathrm{T}$ cells expressing $\mathrm{nAChR} \alpha 7$ subunits [6]. Correspondingly, epibatidine, a highly potent agonist at ionotropic nAChR, failed to mimic the nicotine effect in our present experiments on rat AM.

In contrast to the well-characterized channel properties of nAChR, the mechanisms of atypical nAChR signaling are currently only poorly understood. In peritoneal macrophages, coupling of $\alpha 7 \mathrm{nAChR}$ to the Jak2-STAT3 signaling pathway resulting in STAT3 phosphorylation has been reported [3] which we could not observe in rat AM predominantly expressing $\alpha 9$ and $\alpha 10$ subunits. Membrane bound nAChR subunits have been demonstrated to interact with and to modulate signaling by $\beta$-arrestin [34], phosphatidyl-inositol-3-kinase [35], CD3 [6], and purinergic P2X-receptors [36,37]. The latter are involved in ATP-induced increase in $\left[\mathrm{Ca}^{2}\right.$ $\left.{ }^{+}\right]_{\mathrm{i}}$ by extracellular influx in human AM, since initial $\mathrm{Ca}^{2+}$ transients are reduced by $40 \%$ in $\mathrm{Ca}^{2+}$-free medium [38]. In our present study of rat AM, however, the 


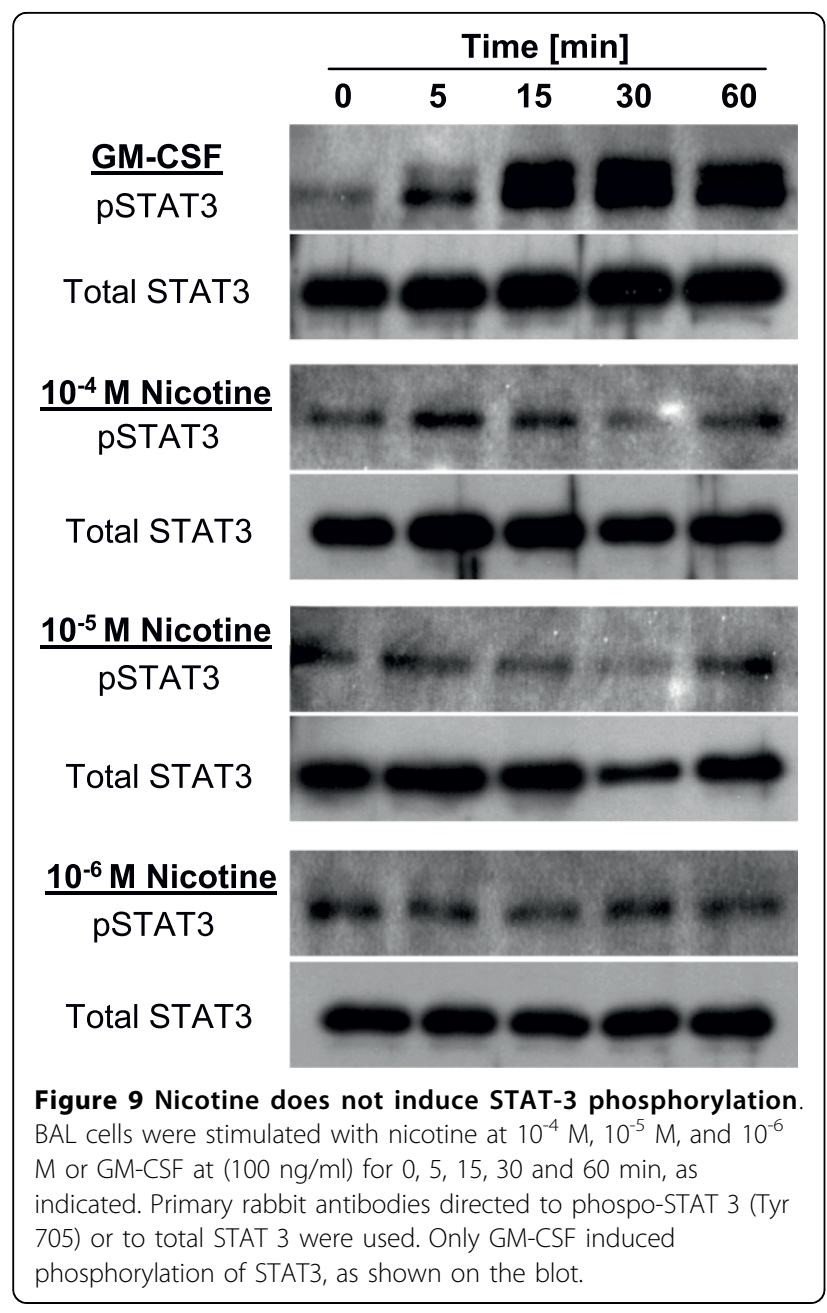

ATP-induced initial increase in $\left[\mathrm{Ca}^{2+}\right]_{i}$ and the modulatory effect of nicotine persisted in $\mathrm{Ca}^{2+}$-free solution, demonstrating interference of atypical $\mathrm{nAChR}$ with $\mathrm{P} 2 \mathrm{Y}$ receptor mediated $\mathrm{Ca}^{2+}$-release from intracellular stores. In support, we observed expression of P2Y purinergic receptors on AM, among them $\mathrm{P}_{2} \mathrm{Y}_{2}$ that mediates $\mathrm{Ca}^{2+}$-release from the endoplasmatic reticulum in mouse macrophages [11].

Extracellular ATP is well recognized as a "danger" or "host tissue damage" signal and is mostly regarded to promote inflammation $[39,40]$. In human AM, it couples to $\left[\mathrm{Ca}^{2+}\right]_{\mathrm{i}}$ increases and stimulates IL- $1 \beta$ and IL- 6 release albeit suppressing TNF $\alpha$ production [38]. In the rat AM cell line NR8383, ATP induces $\mathrm{P}_{2} \mathrm{Y}_{2}$ - and $\mathrm{Ca}^{2+}$-dependent increase in CCL2 synthesis and release [41]. The CCL2-CCR2 axis is a crucial regulator of inflammatory cell influx into the murine lung $[42,43]$. Hence, the presently observed nicotinic attenuation of ATP-induced rise in $\left[\mathrm{Ca}^{2+}\right]_{i}$ can be considered as an anti-inflammatory mechanism triggered by atypical nAChR.

\section{Conclusions}

Rat AM are equipped with modulatory $\mathrm{nAChR}$ with properties distinct from ionotropic nAChR mediating synaptic transmission in the nervous system. Their stimulation with nicotine dampens ATP-induced $\mathrm{Ca}^{2}$ ${ }^{+}$-release from intracellular stores. Thus, the present study identifies the first acute receptor-mediated but atypical nicotinic effect on AM with anti-inflammatory potential.

\section{Competing interests}

The authors declare that they have no competing interests.

\section{Authors' contributions}

$\mathrm{ZM}, \mathrm{PH}, \mathrm{Gl}$ and $\mathrm{ZZ}$ carried out the experimental work and drafted the manuscript. KSL and UP helped with the RT-PCR and immunofluorescence experiments. HK provided antibodies to $\alpha 9$ nAChR subunit. WC, JL, VG, MF participated in the experimental design and in manuscript preparation. WK initiated the study, designed the experiments, and participated in the manuscript preparation. All authors read and approved the final version of the manuscript.

\section{Acknowledgements}

The authors wish to thank Ms. Sigrid Wilker and Mr. Martin Bodenbenner for excellent technical assistance, Dr. Gabriela Krasteva for help with the confocal microscopy and Ms. Karola Michael for help with the art work. This study was supported by the DFG (Excellence Cluster "Cardiopulmonary System" and IntGK 1062) and a grant of the University Medical Center Giessen and Marburg.

\section{Author details}

${ }^{1}$ Institute for Anatomy and Cell Biology, University of Giessen Lung Center, Justus-Liebig-University Giessen, Aulweg 123, D-35385 Giessen, Germany. ${ }^{2}$ Institute of Animal Physiology, Justus-Liebig-University Giessen, Wartweg 95, D-35392, Giessen, Germany. ${ }^{3}$ Division of Pulmonary and Critical Care Medicine, Department of Internal Medicine, University of Giessen Lung Center, Justus-Liebig-University Giessen, Klinikstr. 36, D-35392 Giessen, Germany. ${ }^{4}$ Laboratory of Experimental Trauma Surgery, Department of Trauma Surgery, Justus-Liebig-University Giessen, Kerkraderstr. 9, D-35394, Giessen, Germany. ${ }^{5}$ Department of Dermatology, Venereology and Allergology, University Medical Center Mannheim, Ruprecht-Karls-University Heidelberg, Theodor-Kutzer-Ufer 1-3, D-68135 Mannheim, Germany.

${ }^{6}$ Laboratory of Experimental Surgery, Department of General and Thoracic Surgery, University of Giessen Lung Center, Justus-Liebig-University Giessen, Rudolf Buchheim Str. 7, D-35385 Giessen, Germany.

Received: 30 March 2010 Accepted: 29 September 2010 Published: 29 September 2010

\section{References}

1. Borovikova LV, Ivanova S, Zhang M, Yang H, Botchkina Gl, Watkins LR, Wang $H$, Abumrad N, Eaton JW, Tracey KJ: Vagus nerve stimulation attenuates the systemic inflammatory response to endotoxin. Nature 2000, 405(6785):458-462.

1. Borovikova LV, Ivanova S, Zhang M, Yang H, Botchkina Gl, Watkins LR, Wang $H$, Abumrad N, Eaton JW, Tracey KJ: Vagus nerve stimulation attenuates the systemic inflammatory response to endotoxin. Nature 2000, 405(6785):458-462.

2. Wang H, Yu M, Ochani M, Amella CA, Tanovic M, Susarla S, Li JH, Yang H, Ulloa L, Al-Abed Y, et al: Nicotinic acetylcholine receptor alpha7 subunit is an essential regulator of inflammation. Nature 2003, 421(6921):384-388.

3. de Jonge WJ, van der Zanden EP, The FO, Bijlsma MF, van Westerloo DJ, Bennink RJ, Berthoud HR, Uematsu S, Akira S, van den Wijngaard RM, et al: Stimulation of the vagus nerve attenuates macrophage activation by activating the Jak2-STAT3 signaling pathway. Nat Immunol 2005, 6(8):844-851. 
4. Lukas RJ, Changeux JP, Le Novere N, Albuquerque EX, Balfour DJ, Berg DK, Bertrand D, Chiappinelli VA, Clarke PB, Collins AC, et al: International Union of Pharmacology. XX. Current status of the nomenclature for nicotinic acetylcholine receptors and their subunits. Pharmacol Rev 1999, 51(2):397-401.

5. Peng H, Ferris RL, Matthews $T$, Hiel H, Lopez-Albaitero A, Lustig LR: Characterization of the human nicotinic acetylcholine receptor subunit alpha (alpha) 9 (CHRNA9) and alpha (alpha) 10 (CHRNA10) in lymphocytes. Life Sci 2004, 76(3):263-280.

6. Razani-Boroujerdi S, Boyd RT, Davila-Garcia MI, Nandi JS, Mishra NC, Singh SP, Pena-Philippides JC, Langley R, Sopori ML: T cells express alpha7-nicotinic acetylcholine receptor subunits that require a functional TCR and leukocyte-specific protein tyrosine kinase for nicotine-induced Ca2+ response. J Immunol 2007, 179(5):2889-2898.

7. Hecker A, Mikulski Z, Lips KS, Pfeil U, Zakrzewicz A, Wilker S, Hartmann P, Padberg W, Wessler I, Kummer W, et al: Pivotal Advance: Up-regulation of acetylcholine synthesis and paracrine cholinergic signaling in intravascular transplant leukocytes during rejection of rat renal allografts. J Leukoc Biol 2009, 86(1):13-22.

8. Su X, Lee JW, Matthay ZA, Mednick G, Uchida T, Fang X, Gupta N, Matthay MA: Activation of the alpha7 $\mathrm{nAChR}$ reduces acid-induced acute lung injury in mice and rats. Am J Respir Cell Mol Biol 2007, 37(2):186-192

9. Su X, Matthay MA, Malik AB: Requisite role of the cholinergic alpha7 nicotinic acetylcholine receptor pathway in suppressing Gram-negative sepsis-induced acute lung inflammatory injury. J Immunol 2010, 184(1):401-410.

10. Giebelen IA, van Westerloo DJ, LaRosa GJ, de Vos AF, van der Poll T: Local stimulation of alpha7 cholinergic receptors inhibits LPS-induced TNFalpha release in the mouse lung. Shock 2007, 28(6):700-703.

11. del Rey A, Renigunta V, Dalpke AH, Leipziger J, Matos JE, Robaye B, Zuzarte M, Kavelaars A, Hanley PJ: Knock-out mice reveal the contributions of $\mathrm{P} 2 \mathrm{Y}$ and $\mathrm{P} 2 \mathrm{X}$ receptors to nucleotide-induced $\mathrm{Ca} 2+$ signaling in macrophages. J Biol Chem 2006, 281(46):35147-35155.

12. Mikulski Z, Zaslona Z, Cakarova L, Hartmann P, Wilhelm J, Tecott LH, Lohmeyer J, Kummer W: Serotonin activates murine alveolar macrophages through 5-HT2C receptors. Am J Physiol Lung Cell Mol Physiol 2010, 299(2):L272-80.

13. Gerard GF, Fox DK, Nathan M, D'Alessio JM: Reverse transcriptase. The use of cloned Moloney murine leukemia virus reverse transcriptase to synthesize DNA from RNA. Mol Biotechnol 1997, 8(1):61-77.

14. Krasteva G, Pfeil U, Drab M, Kummer W, Konig P: Caveolin-1 and -2 in airway epithelium: expression and in situ association as detected by FRET-CLSM. Respir Res 2006, 7:108.

15. Dijkstra CD, Dopp EA, Joling P, Kraal G: The heterogeneity of mononuclear phagocytes in lymphoid organs: distinct macrophage subpopulations in the rat recognized by monoclonal antibodies ED1, ED2 and ED3. Immunology 1985, 54(3):589-599.

16. Laemmli UK: Cleavage of structural proteins during the assembly of the head of bacteriophage T4. Nature 1970, 227(5259):680-685.

17. Lips KS, Pfeil U, Kummer W: Coexpression of alpha 9 and alpha 10 nicotinic acetylcholine receptors in rat dorsal root ganglion neurons. Neuroscience 2002, 115(1):1-5.

18. Matsunaga K, Klein TW, Friedman H, Yamamoto $Y$ : Involvement of nicotinic acetylcholine receptors in suppression of antimicrobial activity and cytokine responses of alveolar macrophages to Legionella pneumophila infection by nicotine. J Immunol 2001, 167(11):6518-6524.

19. Galvis G, Lips KS, Kummer W: Expression of nicotinic acetylcholine receptors on murine alveolar macrophages. J Mol Neurosci 2006, 30(12):107-108.

20. Herber DL, Severance EG, Cuevas J, Morgan D, Gordon MN: Biochemical and histochemical evidence of nonspecific binding of alpha7nAChR antibodies to mouse brain tissue. J Histochem Cytochem 2004, 52(10):1367-1376.

21. Prasse A, Stahl M, Schulz G, Kayser G, Wang L, Ask K, Yalcintepe J, Kirschbaum A, Bargagli E, Zissel G, et al: Essential role of osteopontin in smoking-related interstitial lung diseases. Am J Pathol 2009, 174(5):1683-1691.

22. Hajos M, Hurst RS, Hoffmann WE, Krause M, Wall TM, Higdon NR, Groppi VE: The selective alpha7 nicotinic acetylcholine receptor agonist PNU282987 [N-[(3R)-1-Azabicyclo[2.2.2]oct-3-yl]-4-chlorobenzamide hydrochloride] enhances GABAergic synaptic activity in brain slices and restores auditory gating deficits in anesthetized rats. J Pharmacol Exp Ther 2005, 312(3):1213-1222.

23. Meyer EM, Tay ET, Papke RL, Meyers C, Huang GL, de Fiebre CM: 3-[2,4 Dimethoxybenzylidene]anabaseine (DMXB) selectively activates rat alpha7 receptors and improves memory-related behaviors in a mecamylamine-sensitive manner. Brain Res 1997, 768(1-2):49-56.

24. Baker ER, Zwart R, Sher E, Millar NS: Pharmacological properties of alpha 9 alpha 10 nicotinic acetylcholine receptors revealed by heterologous expression of subunit chimeras. Mol Pharmacol 2004, 65(2):453-460.

25. Reynolds PR, Hoidal JR: Temporal-spatial expression and transcriptional regulation of alpha7 nicotinic acetylcholine receptor by thyroid transcription factor- 1 and early growth response factor- 1 during murine lung development. J Biol Chem 2005, 280(37):32548-32554

26. Grau V, Wilker S, Hartmann P, Lips KS, Grando SA, Padberg W Fehrenbach $H$, Kummer W: Administration of keratinocyte growth factor (KGF) modulates the pulmonary expression of nicotinic acetylcholine receptor subunits alpha7, alpha9 and alpha10. Life Sci 2007, 80(2425):2290-2293.

27. Heeschen C, Weis M, Aicher A, Dimmeler S, Cooke JP: A novel angiogenic pathway mediated by non-neuronal nicotinic acetylcholine receptors. J Clin Invest 2002, 110(4):527-536.

28. Moser N, Mechawar N, Jones I, Gochberg-Sarver A, Orr-Urtreger A, Plomann M, Salas R, Molles B, Marubio L, Roth U, et al: Evaluating the suitability of nicotinic acetylcholine receptor antibodies for standard immunodetection procedures. J Neurochem 2007, 102(2):479-492.

29. Millar NS, Gotti C: Diversity of vertebrate nicotinic acetylcholine receptors. Neuropharmacology 2009, 56(1):237-246.

30. Vetter DE, Liberman MC, Mann J, Barhanin J, Boulter J, Brown MC, SaffioteKolman J, Heinemann SF, Elgoyhen AB: Role of alpha9 nicotinic ACh receptor subunits in the development and function of cochlear efferent innervation. Neuron 1999, 23(1):93-103.

31. Vetter DE, Katz E, Maison SF, Taranda J, Turcan S, Ballestero J, Liberman MC, Elgoyhen $A B$, Boulter J: The alpha10 nicotinic acetylcholine receptor subunit is required for normal synaptic function and integrity of the olivocochlear system. Proc Natl Acad Sci USA 2007, 104(51):20594-20599.

32. Zhang GH, Helmke RJ, Mork AC, Martinez JR: Regulation of cytosolic free Ca2+ in cultured rat alveolar macrophages (NR8383). J Leukoc Biol 1997, 62(3):341-348.

33. Wikstrom MA, Lawoko G, Heilbronn E: Cholinergic modulation of extracellular ATP-induced cytoplasmic calcium concentrations in cochlear outer hair cells. J Physiol Paris 1998, 92(5-6):345-349.

34. Dasgupta P, Rastogi S, Pillai S, Ordonez-Ercan D, Morris M, Haura E, Chellappan S: Nicotine induces cell proliferation by beta-arrestinmediated activation of Src and Rb-Raf-1 pathways. J Clin Invest 2006, 116(8):2208-2217.

35. Blanchet MR, Israel-Assayag E, Daleau P, Beaulieu MJ, Cormier Y: Dimethyphenylpiperazinium, a nicotinic receptor agonist, downregulates inflammation in monocytes/macrophages through PI3K and PLC chronic activation. Am J Physiol Lung Cell Mol Physiol 2006, 291(4):L757-763.

36. Khakh BS, Zhou X, Sydes J, Galligan JJ, Lester HA: State-dependent crossinhibition between transmitter-gated cation channels. Nature 2000, 406(6794):405-410.

37. Khakh BS, Fisher JA, Nashmi R, Bowser DN, Lester HA: An angstrom scale interaction between plasma membrane ATP-gated P2X2 and alpha4beta2 nicotinic channels measured with fluorescence resonance energy transfer and total internal reflection fluorescence microscopy. J Neurosci 2005, 25(29):6911-6920.

38. Myrtek D, Muller T, Geyer V, Derr N, Ferrari D, Zissel G, Durk T, Sorichter S, Luttmann W, Kuepper M, et al: Activation of human alveolar macrophages via P2 receptors: coupling to intracellular Ca2+ increases and cytokine secretion. J Immunol 2008, 181(3):2181-2188.

39. Gavala ML, Pfeiffer ZA, Bertics PJ: The nucleotide receptor P2RX7 mediates ATP-induced CREB activation in human and murine monocytic cells. J Leukoc Biol 2008, 84(4):1159-1171.

40. Idzko M, Hammad H, van Nimwegen M, Kool M, Willart MA, Muskens F, Hoogsteden HC, Luttmann W, Ferrari D, Di Virgilio F, et al: Extracellular ATP triggers and maintains asthmatic airway inflammation by activating dendritic cells. Nat Med 2007, 13(8):913-919.

41. Stokes $L$, Surprenant A: Purinergic P2Y2 receptors induce increased MCP$1 / C C L 2$ synthesis and release from rat alveolar and peritoneal macrophages. J Immunol 2007, 179(9):6016-6023. 
42. Maus UA, Koay MA, Delbeck T, Mack M, Ermert M, Ermert L, Blackwell TS, Christman JW, Schlondorff D, Seeger W, et al: Role of resident alveolar macrophages in leukocyte traffic into the alveolar air space of intact mice. Am J Physiol Lung Cell Mol Physiol 2002, 282(6):L1245-1252.

43. Maus UA, Waelsch K, Kuziel WA, Delbeck T, Mack M, Blackwell TS, Christman JW, Schlondorff D, Seeger W, Lohmeyer J: Monocytes are potent facilitators of alveolar neutrophil emigration during lung inflammation: role of the CCL2-CCR2 axis. J Immunol 2003, 170(6):3273-3278

44. Kurzen H, Berger H, Jager C, Hartschuh W, Naher H, Gratchev A, Goerdt S, Deichmann M: Phenotypical and molecular profiling of the extraneuronal cholinergic system of the skin. J Invest Dermatol 2004, 123(5):937-949.

doi:10.1186/1465-9921-11-133

Cite this article as: Mikulski et al:: Nicotinic receptors on rat alveolar macrophages dampen ATP-induced increase in cytosolic calcium concentration. Respiratory Research 2010 11:133.

\section{Submit your next manuscript to BioMed Central} and take full advantage of:

- Convenient online submission

- Thorough peer review

- No space constraints or color figure charges

- Immediate publication on acceptance

- Inclusion in PubMed, CAS, Scopus and Google Scholar

- Research which is freely available for redistribution

Submit your manuscript at www.biomedcentral.com/submit 